\title{
PROGRESS IN THE HOLOCENE CHRONO-CLIMATOSTRATIGRAPHY OF POLISH TERRITORY
}

\author{
LESZEK STARKEL ${ }^{1}$, DANUTA J. MICHCZYŃSKA ${ }^{2}$, MAREK KRĄPIEC ${ }^{3}$, \\ WLODZIMIERZ MARGIELEWSKI ${ }^{4}$, DOROTA NALEPKA ${ }^{5}$ and ANNA PAZDUR ${ }^{2}$ \\ ${ }^{I}$ Institute of Geography and Spatial Organization, Department of Geomorphology and Hydrology of Mountains and Uplands PAS, \\ Św. Jana 22, 31-018 Krakow, Poland \\ ${ }^{2}$ GADAM Centre of Excellence, Institute of Physics, Silesian University of Technology, \\ Krzywoustego 2, 44-100 Gliwice, Poland \\ ${ }^{3}$ AGH, University of Science and Technology, Faculty of Geology, Geophysics and Environmental Protection, \\ Mickiewicza 30, 30-059 Kraków, Poland \\ ${ }^{4}$ Institute of Nature Conservation PAS, Mickiewicza 33, 31-120 Kraków, Poland \\ ${ }^{5}$ W. Szafer Institute of Botany PAS, Lubicz 46, 31-512 Kraków, Poland
}

Received 31 January 2012

Accepted 8 November 2012

\begin{abstract}
The Holocene delivers a unique possibility to establish climatic stratigraphic boundaries based on detailed chronostratigraphy reflected in various facies of continental sediments, in their lithological parameters and organic remains. These sediments are dated by the ${ }^{14} \mathrm{C}$ method in the case of organic remains, by counting annual laminations in lacustrine facies, and by dendrochronological method in the case of fluvial sediments.

The existence of well dated profiles enables to reconstruct various climatic parameters like amplitudes of seasonal temperatures, types and frequency of extreme rainfalls and floods and, finally, to distinguish rare rapid changes and most frequent gradual ones. This reconstruction is based on the analogous effects of various types of present-day rainfalls.

The current authors present a critical review of existing chronostratigraphic divisions starting from simple millennial division by Mangerud based on Scandinavian palynological stratigraphy of peatbogs and Starkel's concept based on fluctuations in rainfall and runoff regime reflected in fluvial and other facies of continental deposits.

In the last decades, the calibration of ${ }^{14} \mathrm{C}$ dates allowed a new approach to be used for the construction of the probability distribution function of these dates in various facies or types of sediments, which formed a background for distinguishing and correlating climatic phases and defining boundaries between them. These approaches have been creating new opportunities for revision of the existing chronostratigraphy.

The aim of this paper is to present a revised version of chronostratigraphic division based on climatic fluctuations reflected in various facies of sediments on the territory of Poland and discuss their correlation with other European regions and global climatic changes.
\end{abstract}

Keywords: Poland, Late Glacial and Holocene, chronostratigraphy, radiocarbon dating, probability density functions.

Corresponding author: D. J. Michczyńska

e-mail: danuta.michczynska@polsl.pl 


\section{INTRODUCTION}

The aim of chronostratigraphy is to detect changes in the measurable time units recorded in the sequences of various sediments and various vegetation and faunal remains. The lithostratigraphy of some continental deposits is frequently discontinuous, only the lacustrine sediment sequences and peatbogs usually register continuous changes.

A range of relatively precise dating methods can be applied for records covering the Holocene epoch, which enables to define stratigraphic boundaries and recognise the rate of changes with a resolution of centuries, decades and even single years. At the same time, the recording of present-day processes facilitates the recognition of annual fluctuations and comparison of them with changes over longer periods, which may be not only of a local character, but also of a regional and even global one.

The aim of this paper is to review the existing records and published attempts to revise a Holocene chronostratigraphy for the territory of Poland and their critical evaluation, especially in the area of quantitative methods used for the sets of radiocarbon dates in various sediment facies. These problems were discussed during the last decade by the Committee for Quaternary Studies of the Polish Academy of Sciences and summarized by the present authors. Simultaneously. the state of the art is an introduction to the revision and new approach to the use of statistical methods for the reconstruction of climatic changes on the territory of Poland during the Late Glacial and Holocene (grant of National Science Centre no. N N306 034040).

\section{Fast and slow climate changes during the Holocene}

Changes in the various sediment facies and in reconstructed ecosystems may proceed faster or slower and, depending on that, they may be more or less helpful in determining stratigraphic boundaries and, in the case of synchronicity of the changes, also chronostratigraphic ones. The rapidly progressing changes in temperature and the accompanying hydrological changes guarantee the formation of sharp boundaries. Such features represent the beginning of the Holocene, recorded in the $\delta^{18} \mathrm{O}$ curve of the Lake Gościąz, where the rapid rise of mean annual temperature by about $4^{\circ} \mathrm{C}$ over several decades caused the creation of a new equilibrium state (RalskaJasiewiczowa et al., 1998, 2003). This does not imply that the response of different systems was simultaneous as they react frequently with a delay reaching centuries (Starkel, 1991), in particular in the mountains.

A fast reaction is recorded also at individual sites during singular or several extreme events like heavy downpours, floods or long-lasting droughts, when the thresholds may be passed, but these events have mainly a local character. In spite of their sharp reflection in the sediment section, the examined system usually returns to the for- mer equilibrium state. An example of such events of great areal extent are the volcanic eruptions (e.g. Laacher See, Krakatau), which are excellent time markers, even though their origin is not connected with chronostratigraphic boundaries.

In the Holocene continental deposits, the gradual changes in temperature are observed as reflected in plant communities, precipitation of calcareous sediments and more or less rhythmic fluctuations in humidity which have been observed since many decades in the oscillations of the mountain glaciers (Golthwait, 1966; Patzelt, 1972; Zoller, 1977; Grove, 1988) and in the fluctuations of the upper tree line (Frenzel et al., 1993).

The detailed analysis of the temperature and precipitation trends during the last, cooler and wetter, phase of the Little Ice Age shows that it consists of several clusters of extremes. Such phases at their beginning are expressed by rapid change in sediment type, shift of vegetation or erosional breaks (hiatuses). Especially in the mountains and their forelands such changes initiate new sediment units connected with, for example, channel avulsions. Frequently, in particular sections this boundary is sharp, but on a regional scale it is mainly delayed by one century or even more and diachronous. The highest lake water level may be dated at the decline of a humid phase and date glacial advances even after the end of that phase (Starkel, 2003; 2006a).

The beginnings of wetter phases, characterised by clusters of heavy rainfalls, since decades have been the basis for setting chronostratigraphic boundaries, for example the one between the Boreal and Atlantic periods at about $8500-8400{ }^{14} \mathrm{C}$ yrs BP (Starkel, $\left.1977 ; 1999\right)$. The declines of such phases are frequently softer due to the lack of clusters or are affected by maturing of plant communities established during the humid phase.

Many papers dedicated to climatic fluctuations during the Holocene have appeared during the last decade. Various records have been used, namely glacial records of Greenland ice cores, Scandinavian and North American, ${ }^{14} \mathrm{C}$ residuals, ice rafting debris (IRD) phases in North Atlantic lake level changes etc. (Bond et al., 2001; Magny et al., 2003; Mayewski et al., 2004 and references cited therein). In most cases authors distinguish 6 periods of significant rapid climate change, present even on the global scale: $9000-8000,6000-5000,4200-3800,3500-$ $2500,1200-1000$ and $600-150$ cal yr BP, in which polar cooling is frequently accompanied by increased humidity. Ice rafting debris phases are more frequent and they repeat every millennium at 9500, 8600, $7500 \mathrm{BP}$ etc. (Bond et al., 2001). The advance phases of glaciers in the Alps do not coincide with other records (Hormes et al., 2001). This has been explained by a different circulation pattern in the belt between $43^{\circ}$ and $50^{\circ}$ northern latitude connected with westerlies activity. A totally different picture, which can be even reverse - with droughts - is obtained in the Mediterranean belt (Magny et al., 2003). 
From this brief review we conclude that the basis of continental records for the climato-chronostratigraphy of the area of Poland differs from the stratigraphy based on ice cores and oceanic deposits. The other question is the lack of a unified definition of rapid climatic change (RCC) which many of the cited authors extend to phases up to 1000 years long. In any case, the wetter phases recognised in the Polish records correlate relatively well with phases of glacial advances and retreats in the Alps (Starkel, 2002 and 2003; Margielewski, 2006).

This zonal diversification is also confirmed by the pattern of the dendrochronological master chronologies. Absolutely dated dendrochronological standards for oak from southern Poland from the last 4000 years display substantially higher convergence with the South Germany standards than with the North Poland chronology (Krąpiec, 1992 and 1996).

\section{History of the chronostratigraphical division of the Holocene}

The Blytt-Sernander sequence (Blytt, 1882; Sernander, 1908) was the first well-developed, widelyused subdivision of the Holocene and Late Glacial. Lateand Post- Glacial pollen succession was initially determined in western and north-western Europe by Jessen (1935), Nilsson (1935), Godwin (1940 and 1956), and Firbas $(1949 / 1952,1954)$. It should be noted that at the same time in Europe a three-part division into Eo- Mesoand Neo-Holocene, based on thermal changes, was implemented (Firbas, 1954; Neustadt, 1957). In the 1970s, radiocarbon dating started to define the basic time scale. In the climatically oriented chronostratigraphy of the Holocene the boundaries were defined on the basis of the complete records of forest changes visible in pollen diagrams obtained for lake and mire deposits (Firbas, 1954; Nilsson, 1935). The lack of the synchronicity led Mangerud et al. (1974) to construct a stiff scale for thousands of radiocarbon years with holding the traditional, widely accepted names: Bølling, Allerød, Younger Dryas, Preboreal, Boreal, Atlantic, Subboreal and Subatlantic. That terminology, which was originally developed for biostratigraphical zones, has been used throughout northern and western Europe in a chronostratigraphic sense (Mangerud et al.,1974; Hoek, 2008).

Starkel (1977, 1991(Ed.)) in his division for Poland and Central Europe, based mainly on the alluvial and slope sediments, preserved the three-part division (Eo-, Meso- and Neo-Holocene) but introduced more details concerning better marked beginnings of several humid phases and shifted some boundaries defined by Mangerud et al. (1974), leaving their traditional Scandinavian names (Fig. 1).

Boundaries introduced by Mangerud and Starkel are based on results of radiocarbon dating and expressed as conventional ages. Raw radiocarbon ages, reported in "years Before Present" (BP) are equal to the number of radiocarbon years before 1950. They are calculated as- suming a constant level of ${ }^{14} \mathrm{C}$ concentration in the atmosphere. Moreover, these raw ages are based on a slightly-off historic value for the ${ }^{14} \mathrm{C}$ half-life - so called Libby's value equals to $5568 \pm 30$ years (Arnold and Libby, 1951). In 1962 an updated figure of $5730 \pm 40$ years was accepted (Godwin, 1962), but laboratories continue to use the Libby figure to avoid inconsistencies with earlier publications. In 1958, de Vries demonstrated that the assumption of constant ${ }^{14} \mathrm{C}$ concentration is erroneous. It took many years before changes in the concentration of ${ }^{14} \mathrm{C}$ in the past were reconstructed. The first internationally accepted calibration curve, published in 1986 (Stuiver and Pearson, 1986; Pearson and Stuiver, 1986), covered past 8000 years, whereas the last version of the calibration curve (IntCal09, Reimer et al, 2009) covers 50,000 years. Starting from publishing calibration curves, the procedure for probabilistic calibration of radiocarbon dates has been developing (e.g. Stuiver and Reimer, 1986; Aitchison et al., 1989; Buck et al., 1991; Michczyńska et al., 1990; Bronk Ramsey, 1995; 2001 and 2006).

The adaptation of calendar scale forces a revision of the practical but stiff division into chronozones proposed by Mangerud or Starkel. The simplest solution, namely a calibration of Starkel's boundaries (1977), unfortunately does not give unambiguous results. In Fig. 1 (right side of the figure) results of calibration of these boundaries are presented. It was assumed that all boundaries have got the same uncertainty of ${ }^{14} \mathrm{C}$ age equal to 100 years. In most cases, the obtained distributions of calendar ages are wide and multimodal. In the authors' opinion the analysis of large data sets can be helpful in a more accurate determination of the value of these boundaries (see next Chapters).

The most valuable archive for synthesis presented on a calendar time scale are annually laminated sediments like those found in Lake Gościąż (Ralska-Jasiewiczowa et al. (Eds.), 1998). Chronostratigraphy based on highresolution sediments could be a key stratigraphy for different geographical regions. Unfortunately, there are only a few elaborated such records for Poland territory and study of annually laminated lacustrine sediments are only in their beginnings (see http://www.norpolar.ug.edu.pl/). Moreover, the lakes are typical only for Northern Poland. In this situation, the analysis of big sets of radiocarbon dates for different types of sediments could be helpful in more precise establishing of these boundaries (see Chapter 2).

\section{Divisions of the Polish Holocene on the basis of pollen analysis}

The vegetation changes are characterized by the sequence of pollen zones in the palynological diagram. The identified bio-stages have a local meaning and even if the analysed layers originate from geographical locations distant from one another they may represent the same type of climatic changes. Since 1970s, pollen diagrams 


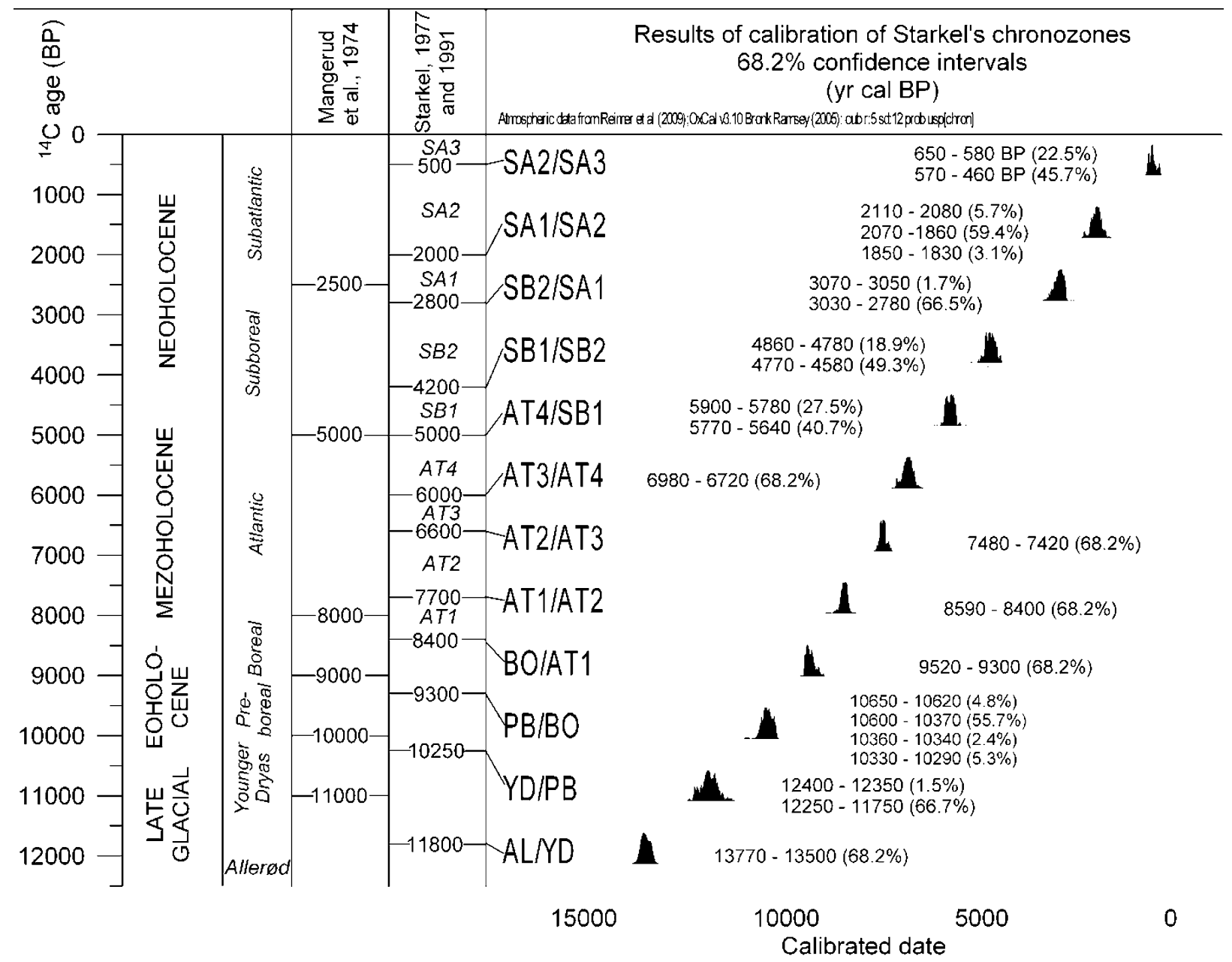

Fig. 1. Chronostratigraphical subdivisions of the Holocene according to Mangerud et al. (1974) and Starkel (1977; 1991). On the right side, the results of calibration of the Starkel's chronozone boundaries are presented. It was assumed that all boundaries have got the same uncertainty of the ${ }^{14} \mathrm{C}$ age equal to 100 years. Results of calibration are ambiguous (see text).

are divided into local pollen assemblage zones (LPAZ) in the sense of Birks $(1979,1986)$ on the basis of visual analysis of individual pollen curves, supported by numerical analysis, e.g. CONISS, ConsLink, PCA (Nalepka and Walanus, 2003). In that way, combined with radiocarbon dates, the synthesis of vegetation changes in Europe in the last 15000 years was constructed (Berglund et al., 1996). Usually, the published reconstructions were expressed in ${ }^{14} \mathrm{C}$ years. Some step toward reconstructions presented on absolute time scale is a publication dedicated to annually laminated sediments from Lake Gościąż (Ralska-Jasiewiczowa et al. (Eds.), 1998) and Lake Perespilno (Goslar et al., 1999). Another work that should be mentioned is the synthesis for Poland, based on isopollen maps (Ralska-Jasiewiczowa et al. (Eds.), 2004), where the authors, in addition to the results presented on the ${ }^{14} \mathrm{C}$ scale, added a chapter entitled "Calendar ages of the time horizons presented on the isopollen maps" (Walanus and Nalepka, 2004).

\section{Divisions of the Polish Holocene on the basis of mala- cological analysis}

In the research of the environmental changes the malacological analysis is also used, especially in regions built of calcareous rocks. It is based on the division of molluscs into ecological groups proposed by Ložek (1964) and subsequently modified by S.W. Alexandrowicz (1987). The fractions of the species assigned to individual ecological groups constitute reference material for palaeoenvironmental reconstructions. The succession of molluscs provides a possibility of reconstruction of changes of climate and habitat conditions, particularly within carbonate sediments, devoid of plant pollen. The presence of certain taxa also enables indirect dating of sediments. In contrast to some other methods, the malacological analysis gives a possibility of detailed reconstruction of local conditions (Alexandrowicz, 2001). The material coming from many sites serves as a basis for regional reconstructions (Alexandrowicz, 1997b and 2004), as 
well as for malacostratigraphical schemes (Alexandrowicz, 2009).

\section{Litho- and morphostratigraphic divisions}

Starkel (1966) in his review paper on the European Holocene stressed the role of alluvial deposits and forms for the climatostratigraphy, especially through discovery of several cuts and fills with abandoned river channels in the Vistula River catchment (Starkel, 1960, 1983; Starkel (Ed.), 1990; Kalicki, 1991), also known from the Rhine catchment (Schirmer, 1983; Brunnacker, 1978) and other catchments (Starkel et al., 1991). The dating of fills as well as palaeochannels helped to distinguish several phases connected with more humid and usually cooler phases and to correlate them with advances of Alpine glaciers (Patzelt, 1972), lowering of upper timber line (Frenzel et al., 1993), expansion of permafrost (Kotarba and Baumgart-Kotarba, 1997), fluctuation of lake level (Magny, 1993) and intensification of mass movements (Starkel, 1997; Alexandrowicz, 1997a; Margielewski, 2006).

It was possible to identify sediment layers related to single events such as downpours and floods. In the last millennia, the human activity, mainly deforestation, superimposed on climatic changes, caused accelerated soil erosion and aggradation (Starkel, 1987 and 2005). As a result, especially since the Roman times, we cannot interpret all changes as a signal of palaeoclimatic variations.

\section{Frequency distribution of radiocarbon dates as a tool for reconstructing environmental changes for the terri- tory of Poland}

Since the 1970s, analyses of the time scale distribution of radiocarbon dates have been carried out for selected regions of Europe (e.g. Geyh and Streif, 1970; Geyh, 1980, Macklin et al., 2006), Asia (e.g. Kuzmin and Keates, 2005), Africa (e.g. Geyh and Jäkel, 1974), America (e.g. Rick, 1987; Peros et al., 2010; Michczyńska and Hajdas, 2010) and Australia (e.g. Williams, 2012).

Since the 1980s, similar interpretations of the time scale distribution of dates have been published for the territory of Poland. These interpretations concerned different sediment facies containing organic remains or carbonates: peat, lake sediments, fluvial sediments, tufas, speleothems and landslides (Pazdur and Pazdur, 1986; Goździk and Pazdur, 1987; Pazdur et al., 1995; Michczyńska and Pazdur, 2004; Starkel et al., 2006; Margielewski, 2006; Michczyńska et al., 2007). At the beginning, the analysis of the frequency distributions of radiocarbon dates was limited to the radiocarbon scale. Pazdur and Pazdur (1986) presented a frequency distribution of ${ }^{14} \mathrm{C}$ dates for the time interval $10,000-15,000{ }^{14} \mathrm{C}$ yrs BP for all radiocarbon measurements made before 1985 in the Gliwice Radiocarbon Laboratory $\left(120{ }^{14} \mathrm{C}\right.$ dates). The authors found maxima corresponding to the Bølling and Allerød, and minima connected with the
Older and Younger Dryas. The onset of the Holocene was marked by a sharp increase in the frequency of radiocarbon dates. Goździk and Pazdur (1987) presented a frequency distribution of $193{ }^{14} \mathrm{C}$ dates for the time interval $12,000-45,000{ }^{14} \mathrm{C}$ yrs BP. The authors concluded that the reconstructions are in agreement with existing palaeoclimatic information. Both mentioned studies confirm the usefulness of frequency distribution of ${ }^{14} \mathrm{C}$ dates for environmental reconstructions during cold periods when the temperature was the main factor controlling the growth of plants.

The paper by Pazdur et al. (1995) presents frequency distributions of ca. $150{ }^{14} \mathrm{C}$ dates of speleothems from the Kraków-Wieluń Upland (southern Poland) for the time interval $0-50{ }^{14} \mathrm{C}$ ka BP. The growth of speleothems require moist and warm conditions, but in most cases, the temperature seems to be the major control factor. The main period of speleothems deposition fell within the Meso-Holocene, so called climatic optimum.

Michczyńska and Pazdur (2004) presented basic assumptions of the shape analysis of the frequency distribution of ${ }^{14} \mathrm{C}$ dates set in the study of environmental changes, evaluated a minimum number of dates required to receive reliable results, and discussed the influence of the smoothing of the calibration curve. The authors presented frequency distribution for $785{ }^{14} \mathrm{C}$ dates of peat samples. The weakness of this collection is that peat is deposited in various environments and may reflect either wet phases with intensive peat growth, or just the opposite, the drier phases connected with lowering of lake levels and their overgrowth. Moreover, the influence of other factors was also not considered, e.g. various time of dead ice melting; the natural trend to gradual overgrowth of lake depressions progressing from their margin or human impact on fluctuations of groundwater table caused by deforestation and drainage. Therefore, the palaeoclimatic interpretation of shape of frequency curve is not straightforward.

Frequency distribution of dates on the calendar time scale (probability density function - PDF) is obtained by summing up probability distributions of individual dates after calibration and using appropriate normalization. Good agreement of the shape of PDF and other environmental data was obtained by Michczyńska and Pazdur (2004). The correlation with $\delta^{18} \mathrm{O}$ and methane concentration curves recorded in the Greenland ice core GRIP and changes of $\delta^{18} \mathrm{O}$ in the Lake Gościąż sediments for the Late Glacial/Holocene transition testified the validity of the method for climate reconstruction for Late Glacial period. The authors noticed also the presence of high narrow peaks in the PDF, and because of coincidence of these peaks with the localization of limits between the earlier established Holocene chronozones (Starkel, 1977), suggested that such peaks might be a result of the sampling methodology. The general rule of taking samples from places of visible sedimentation changes, e.g. from the top and bottom of the peat layer, or from places where changes in pollen diagram are ob- 
served, may be the reason that samples from limits between the chronozones are collected more frequently. This fact could be helpful in establishing the Holocene chronostratigraphy on the calendar scale.

In the frame of the GLOCOPH Project (Past hydrological events related to understanding Global Change" funded by the International Council for Science and led by Professor K.J. Gregory (Gregory et al., 2006; Macklin et al., 2006) a database of 335 radiocarbon dates from Holocene fluvial sediments in Poland has been compiled (Starkel et al., 2006). The main aim was to find horizons reflecting changes in the fluvial regime, mainly in the frequency of floods. Several clearly identified groups of dates were selected. The PDF received for dates from the bottom of palaeochannels (149 dates) clearly reflected the age of avulsion of river channels and then major wetter phases of the Holocene. Other picture was presented by the start of overbank aggradations (86 dates) connected mainly with floods during periods of expansion of agriculture. The authors identified up to 17 flooding phases, but only 10 of them include a distinct sharp peak concentrated in one century indicating distinct changes in fluvial regime, e.g. beginnings or ends of phases with frequent floods.

Phases of deep landslide formation in the Polish flysch Carpathians have been established in conventional (BP) age on the basis of radiocarbon dating of landslides (Gil et al., 1974; Starkel, 1997; Alexandrowicz, 1996 and 1997a; Margielewski 1998). Margielewski (2006) used sets of radiocarbon dates of 66 landslide forms for the construction of the Probability Density Function, to establish more than 10 phases of the landsliding, connected with phases of climate humidity growth, during which an increase in frequency and intensity of extreme hydrometeorological events was recorded. During these wet climatic phases, numerous landslide forms, or their rejuvenation processes were formed due to heavy rainfalls (or continuous rains) and intensified fluvial erosion.

The above-mentioned studies permit to conclude that analysing PDFs of different types of sediments can be helpful in the qualitative reconstruction of the past environment. The PDF for peat samples primarily reflects palaeohydrological conditions but of unidentified origin and direction; the PDFs for speleothem and tufa samples reflect both changes in temperature and humidity, while analysis of the PDF for fluvial data and landslide formation shows phases of increased frequency of extreme hydrological events.

\section{MATERIALS}

The aim of this paper is to evaluate the existing approaches and on the basis of them try to revise the previous stratigraphy and construct a new version of chronostratigraphic division based on climatic fluctuations reflected in various facies of sediments on the territory of
Poland and try to correlate them with other European regions and climatic changes in higher latitudes.

This paper presents datasets collected in the earlier studies: comprehensive sets of ${ }^{14} \mathrm{C}$ dates for fluvial data (Starkel et al., 2006), peat samples (Michczyńska and Pazdur, 2004), speleothems, tufas (Pazdur et al., 2002a and 2002b; Michczyńska et al., 2007), landslides (Margielewski, 2006) and also dates of deposition of subfossil oak trunks (Krapiec, 1992; 1996; 2001), debris flows in high mountains (Kotarba and Baumgart-Kotarba, 1997) information about changes of lake water level (RalskaJasiewiczowa, 1989) and vegetation changes (RalskaJasiewiczowa and Starkel, 1988; Ralska-Jasiewiczowa and Latałowa, 1996; Ralska-Jasiewiczowa et al. (Eds), 1998). These records are gathered and synthesized in order to evaluate calendar ages of the chronozones. The majority of analysed ${ }^{14} \mathrm{C}$ dates come from Gliwice Radiocarbon Laboratory, only 148 dates come from other radiocarbon laboratories. In our analysis, the most numerous are sets of fluvial and peat dates and they are the most representative. Other datasets play a support role. Usually, from one site, one or two ${ }^{14} \mathrm{C}$ dates were chosen for analysis. This way we avoid overrepresentation of local signal. Sets of data were also verified to avoid repeated dates in different sets (disjoint sets of ${ }^{14} \mathrm{C}$ dates) or to exclude dates of possibly redeposited samples. Short synthesis of the used data is presented below.

\section{Fluvial data}

The database of past hydrological events for the territory of Poland comprises ca. $700{ }^{14} \mathrm{C}$ dates, but only 335 which fall into the listed below sample categories reflecting either flood periods or distinct change of hydrological regime were selected for analysis (Starkel et al., 2006):

1) organic remains preserved in channel deposits in the form of lenses and smaller organic fragments, which are synchronous with mineral deposits and probably were not redeposited; tree trunks are generally excluded from this group,

2) organic remains at the base of abandoned palaeochannels that postdate the avulsion or cut-off of the river channel,

3) organic matter (peat, organic mud) from the top of overbank facies, buried by channel deposit; here event is younger than date, assuming that organic layer was not truncated,

4) peat or fossil soil buried by a younger overbank flood event,

5) channel facies buried by overbank deposit with organic remains, where event is older than the date,

6) mineral intercalation in peat sequence dating a short flood event on a peaty floodplain,

7) base of peat overlying overbank facies, dating floods older than date,

8) organic intercalation in overbank deposits, which date should be synchronous with the phase of deposition. 
Samples were also grouped into regions differing in physiography and type of floods.

Alluvia and fluvial forms reflect changes connected with varying frequency of floods, changes from suspended load to bed load and erosion, changes in channel size and avulsions. Several wetter phases are represented by members composed of many layers deposited during singular floods (Niedziałkowska et al., 1977; Starkel, 1995).

\section{Peatbogs}

The set of $785{ }^{14} \mathrm{C}$ dates was chosen to test the possibility of environmental reconstruction on the basis of the shape of PDF. Michczyńska and Pazdur (2004) assumed that the number of samples dated by the ${ }^{14} \mathrm{C}$ method is proportional to the amount of organic matter deposited in sediments in the studied time intervals. In other words, they assumed random character of dates - the dates originated from a large territory of the whole Poland, with the exception of the Baltic Coastland, and different investigators who collected them were interested in various disciplines. The authors concluded that peaks and gaps of the constructed PDF allow determining periods with favourable and unfavourable conditions for peat sedimentation. The main trends of PDF is in good correlation with the shape of the methane concentration curve in the GRIP ice core (Michczyńska et al., 2007) if we disregard the high narrow peaks. Because methane is formed mainly by the decomposition of organic matter in boggy continental areas, and methane concentration changes are an indicator of climate humidity, then the observed correlation indicates that information about changes in humidity should be also stored in frequency distribution of peat samples.

The presence of high narrow peaks is connected with the sampling methodology. A random character of a large part of the chosen set can be assumed, but the general tendency to collect samples from the places of visible sedimentation changes results in the presence of these PDF peaks near the boundaries of the earlier established Holocene subdivisions.

For the purpose of this study, to receive disjoint data sets, the set of ${ }^{14} \mathrm{C}$ dates for peat samples was modified by excluding dates common for this set and for the set with fluvial data. Finally, $709{ }^{14} \mathrm{C}$ dates for peat samples were selected.

\section{Landslide forms and deposits}

The intensification of mass movements is considered to be connected with the climate moistening resulting in a growth of heavy rainfalls and/or long-lasting rainy seasons (Starkel, 1997; Alexandrowicz, 1996 and 1997a). Until now 69 radiocarbon dates for various sample materials were collected for landslide sites in the Polish Flysch Carpathians (e.g. Gil et al., 1974; Alexandrowicz, 1996; Margielewski, 1998 and 2006; Wójcik et al.,
2006), which makes this dataset significant. Simultaneously on the basis of the lichenometric dating of several tens of landslides in the Western Carpathians more than ten episodes of landslide formation and rejuvenation during the last 500 years were determined (BajgierKowalska, 2008).

The second dataset comprises the radiocarbon dates of illuvial and minerogenic horizons deposited during heavy downpours within the sequences of peat-bogs filling the landslide depressions (Margielewski (Ed.) 2003; Margielewski, 2006; Margielewski et al., 2010). Analysis of the thickness and lithology of these horizons enables to distinguish individual events from groups and series of events related to climate phases (Margielewski, 2006; Starkel, 2006b). Currently, the database comprises 98 dates (selected from more than 140 dates) which usually determine the beginning of illuvial or minerogenic horizons' deposition in peat-bogs. The selection consisted in the exclusion of doubled age determinations in each diagnostic mineral horizon from the set and in the selection of one representative date for each horizon in every landslide peat bog.

\section{Debris flows in the Tatra Mountains}

Dated horizons of coarse grained sediments of the lacustrine depositional sequences in the Tatra Mountains are generated during short but intensive rainfalls and subsequent avalanches, by rockfalls, and - most of all debris flows (Baumgart-Kotarba and Kotarba, 1993; Kotarba, 1996). Within sediments of several lakes more than 20 samples of high-energetic inserts were dated using the radiocarbon method in order to determine the debris flows' activation during the Late Glacial and Holocene (Baumgart-Kotarba and Kotarba 1993; Kotarba and Baumgart-Kotarba, 1997). For the last ca. 500 years the debris flows and rock falls were dated by the lichenometric method (Kotarba, 1995 and 2006) and the high-energetic lacustrine horizons deposited in the last 150 years - by the ${ }^{210} \mathrm{~Pb}$ method (Baumgart-Kotarba et al., 1993). Because only small numbers of samples (ca. 20) were dated by ${ }^{14} \mathrm{C}$ method these data play only support role and not presented in graphical form.

\section{Speleothems}

Speleothems deposition is connected with conditions of high temperature and relatively high precipitation (Pazdur et al., 1995; Pazdur et al., 1999a and 1999b; Pazdur 2000). Speleothems used in this study come from caves of the Cracow-Wielun Upland and were dated in the Gliwice Radiocarbon Laboratory (Gradziński et al., 2003; Pazdur et al., 1999a). From 41 caves the 89 speleothem dates were selected, which usually date the end of precipitation phase.

The estimated reservoir effect correction of 1650 years was applied for all dated speleothems (Goslar et al., 2000; Pazdur et al. 1999b), which is obviously a simpli- 
fied assumption, however, the only possible one at the moment.

\section{Calcareous tufas}

Radiocarbon dates of tufas are from 100 samples which represent 3 calcareous regions: Cracow-Wieluń Upland (27 samples), Holy-Cross Mts. (11 samples) and Lublin Upland (63 samples). Tufas were deposited in the stream channels, and also within cupola spring mires characteristic for part of the Lublin Upland (Dobrowolski et al., 1999; Pazdur 1988; Pazdur et al., 1988; Pazdur et al., 2002a and 2002b). $\mathrm{CaCO}_{3}$ precipitated in conditions of relatively higher temperature. Because of this fact, tufas are a good indicator of warm climate, although a productivity of springs also influences sediment formation (Pazdur et al., 1988; Pazdur et al., 2002a and 2002b). Apparent age correction dependent on the site and type of calcareous tufas was introduced to all dates on the basis of measurements of the age of organic matter associated with them.

\section{Subfossil oaks in river sediments}

Subfossil trunks are a good indicator of the frequency of floods. The tree trunks have been accumulated in the river sediments, as a result of the lateral erosion causing migration of the river channels. During floods the trees growing on floodplains fell into the river, were subsequently transported and deposited among the channel sediments. As the trunks slowed the river current, they were relatively quickly covered with sediments (Kalicki and Krapiec, 1995). In the Holocene alluvia the accumulation of tree trunks, mainly of oaks, has been encountered at various depths. Felling the trees due to migration of the river channels did not occur evenly (Becker, 1982; Delorme and Leuschner, 1983; Krapiec, 1992). Beside the periods characterised by considerable amounts of trunks, others occurred, in which trunks appeared only occasionally. The first ones are considered as periods of more intense activity of the rivers connected with phases of increased humidity and cooler weather, in which river channels migrated and the sedimentation rate varied (Starkel, 1983; Starkel et al., 1996a). Apart from climatic conditions, the human activity had certain impact on the accumulation and erosion rate, as the deforestation of river valleys and slopes triggered the supply of clastic material.

During over 20 years of the investigations of the subfossil oaks about 1100 samples were taken for dendrochronological analyses. On the basis of 400 samples the absolute chronologies representing the last four millennia were established (Krąpiec, 1998; 2001). Absolutely dated annual growth sequences of the trunks permitted to outline the time of sowing and felling the individual oaks with an accuracy of a few years. The juxtaposition of the beginnings of growth and felling of the oaks in the 25- year periods gave the basis for the identification of phases of the intensification of the river activity.

\section{Fluctuation of lake water level}

There exist various methods indicating the variations of lake water level, which are controlled by changes in humidity and precipitation.

The most frequent are analyses of sediment sequences in the littoral zone by observing the intercalations of peat, gyttja and lacustrine chalk (Ralska-Jasiewiczowa and Starkel, 1988; Ralska-Jasiewiczowa and Latałowa, 1996, Ralska-Jasiewiczowa et al. (Eds), 1998), often supplemented by the existence of lacustrine terraces indicating phases of the highest water levels (Starkel et al., 1996, Niewiarowski et al., 1995). The other important proxy of water level is the relative abundance of organic species, among them the Cladocera analysis (e.g. Szeroczyńska, 1998, Zawisza and Szeroczyńska 2007; Szeroczyńska and Zawisza, 2011).

But in Northern Poland occupied by the last Scandinavian ice sheet with hundreds of lakes we should take into consideration other factors influencing the fluctuations of lake levels (Starkel, 2003). First of all, the melting of dead ice blocks, which has been continuing until early Holocene (Niewiarowski, 1987) caused a rise of lake level. Moreover, the decrease of the lake level could have been caused by overgrowing by peat bogs and draining combined with formation of new river systems after deglaciation (Nowaczyk and Okuniewska-Nowaczyk, 1999, Nowaczyk et al., 2002). Finally, filling of lake basins by various kinds of sediments (Starkel et al., 1996b) resulted in a gradual rise of lake level during the Holocene.

\section{METHODS}

The location of chronostratigraphic boundaries was evaluated on the basis of the shape of PDF's for different type of sediments supported by compilation of information about lithostratigraphy, lake level changes and trends in temperature resulting from palynological diagrams for key sites (Ralska-Jasiewiczowa and Starkel, 1988; Ralska-Jasiewiczowa and Latałowa, 1996). We decided to place the boundaries usually at the half of the growing slope of PDF curves, but we also took into account that some phenomena are delayed in time in relation to climate impact (e.g. abandonment of palaeochannels, see Starkel, 1983). In the establishing of the onset of Younger Drays and the Holocene, the appropriate boundaries for annually laminated sediments from Lake Gościąż were also taken into account (Goslar et al., 1998; Różański et al., 2010).

The selection of ${ }^{14} \mathrm{C}$ dates for subsequent data sets was based on different principles depending on the archive type, and therefore the climatostratigraphic and chronostratigraphic interpretations are subjective to different limitations. Only one from the analysed sets of data 
was not constructed by choosing samples (and ${ }^{14} \mathrm{C}$ dates) characteristic for the investigated phenomenon - the peat samples set. The rest of investigated data were connected with the age evaluation of the beginning and end of climatic phases or represent short episodes (e.g. floods).

The constructed PDF curves reflect mainly periods of changes in the environment and could be helpful in definition of boundaries of chronozones on the basis of the shape of PDF curves. Dated events which were characteristic for local environments form a background (information noise) whereas events which were characteristic for given regions, or for whole Poland are marked by clear peaks on the PDF curves. It seems obvious that the faster change in the environment the narrower peak could be expected. It is worth to stress that also the shape of the calibration curve influences the shape of PDFs and in some periods of time it works like an amplifier (Michczyński and Michczyńska, 2006).

The peat samples set is a set of random data, but observed earlier facts testify its usefulness for chronostratigraphic investigations (Michczyńska and Pazdur, 2004; Michczyńska et al, 2007). In the case of this set, the main shape of the PDF curve reflects conditions favourable and unfavourable for peat sedimentation. On the main trend of the curve, connected with environmental conditions are placed high narrow peaks resulting from preferential sampling. Their positions could be used for evaluation of chronostratigraphic boundaries.

\section{RESULTS}

The authors decided to collect previously published frequency distribution curves for different types of sediments, discuss them once more and present in the form of one overall graph together with compiled information about temperature, precipitation and stratigraphy (Fig. 2). All presented PDFs were obtained using the OxCal programme (Bronk Ramsey 1995; 2001; 2006) and the calibration curve IntCal09 (Reimer et al., 2009).

\section{Fluvial data (Fig. 2a-c)}

The probability density curves of ${ }^{14} \mathrm{C}$ dates coinciding with the change in sedimentation type can be attributed to main flood episodes. From the dates representing directly alluvial members of channel facies (Fig. 2a) two groups were selected. Those groups represented the starts of filling of abandoned palaeochannels (Fig. 2b) and organic layers or soils covered by overbank sediments which initiated a new phase of deposition (Fig. 2c). Many of these dates from the top or base of organic layer either predate or postdate the start of a new climatic phase (Starkel et al., 2006). Abundance of palaeochannels (Fig. 2b) were dated by samples from the bottom of fossil palaeochannel after its avulsion, and age of avulsion or cut-off may be some decades older than the start of organic deposition. Dates for peat or soil covered by overbank facies (Fig. 2c) - the deposition of thick layer of silt or sand indicate periods of floods (or single flood) and their thickness is usually related to phase of human agricultural activity.

The probability density functions help to distinguish the following climatostratigraphic borders, especially well visible in the foreland of the mountains. The first rise is observed at the beginning of Allerød at ca. 14,000 cal BP. After lower values during the Younger Dryas the rise coincides with the start of the Holocene $(11,500 \mathrm{cal}$ $\mathrm{BP}$ ), which is especially visible in the great number of great Late Glacial abandoned channels (Starkel, 1991). This phase continues until ca. 10,500 cal BP. Next distinct rise of fluvial activity coincides with early Atlantic phase, between 9600 and $8400 \mathrm{cal} \mathrm{BP}$, which is marked by two peaks at the beginning and at the end of the phase (Starkel et al., 1996; 2006). This humid phase is independently documented by about 100 flood events recorded in one alluvial fan at Podgrodzie (Niedziałkowska et al., 1977; Starkel et al., 1996; Czyżowska, 1997). A minor rise is recorded about 7700 cal BP and afterwards a higher one with two peaks after 6400 and before $5600 \mathrm{cal}$ $\mathrm{BP}$. The last one coincides with the abandonment of many palaeochannels at the gradual transition from Atlantic to Subboreal. Next humid phases of flood activity start about 4800,3700 and 2800 cal BP. Higher activity is recorded in 1900-1800 cal BP (mainly in overbank facies) and in 1600-1500 cal BP with a great number of channel avulsions. Last distinct phase reflected in ${ }^{14} \mathrm{C}$ records connected both with cooling and with increased human activity started from $1000 \mathrm{cal} \mathrm{BP}$.

\section{Peatbogs (Fig. 2d)}

The general feature of the PDF for this set of radiocarbon dates is in accordance with the result for fluvial data. The Bølling-Allerød warming is marked by a rise of the PDF curve highest at the end, reflecting peat formation in dead-ice depressions before the formation of lakes. The transition Allerød/Younger Dryas (12650 cal $\mathrm{BP}$ ) is marked by a rapid falling slope, and Younger Dryas/Preboreal (11500 cal BP) as a slowly growing slope of the PDF curve. The last boundary is blurred. Boundaries Preboreal/Boreal (10200 cal BP) and Boreal/Atlantic (9500 cal yr BP) are marked by high narrow peaks. The next boundaries, showing changes in the composition of vegetation inside the Atlantic Phase: AT2/AT3 (7700 cal BP), AT3/AT4 (6400 cal BP), as well as boundaries Atlantic/Subboreal (5600 cal BP, and 4850 cal BP) and Subboreal/Subatlantic (2850 cal BP) are also distinct. Results for this set, together with results for fluvial data are the main base for chronostratigraphical divisions.

\section{Landslide data in Flysch Carpathians (Figs. 2e, f)}

The first peaks of the PDF curve of the ages of the landslides and minerogenic horizons, with a maximum at ca. 13,250 cal BP are connected with the climate warm- 


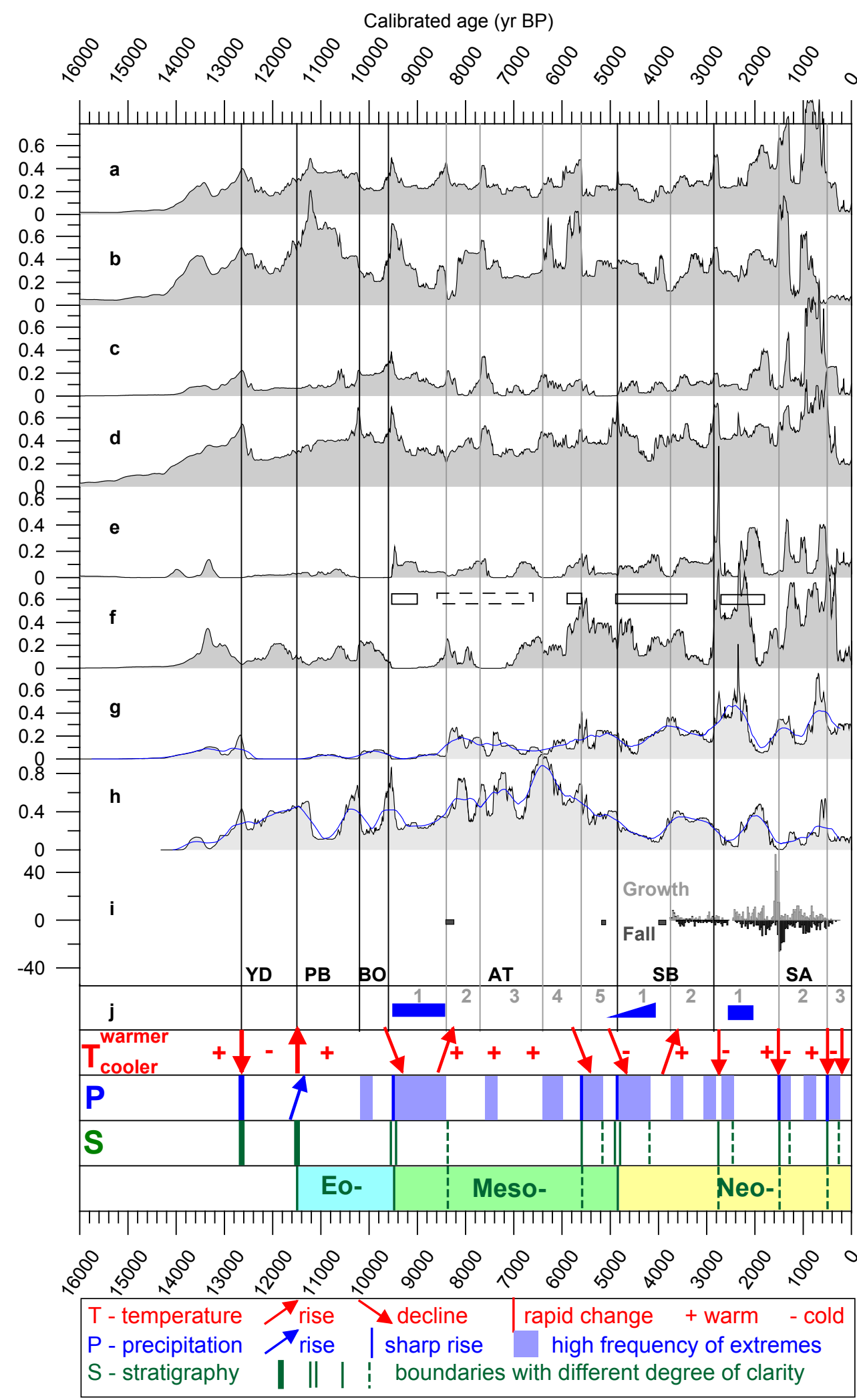

Fig. 2. Probability density functions (PDFs) constructed for different type of sediments from Polish territory. Curves were constructed with using the option "Sum" in OxCal programme, (Bronk Ramsey, 2006) and calibration curve IntCal09 (Reimer et al., 2009): a - fluvial data (334 ${ }^{14} \mathrm{C}$ dates), $b$ - fluvial data subset, selected dates represent abandonment of palaeochannels (151 ${ }^{14} \mathrm{C}$ dates), c - fluvial data subset - dates of peat or soil covered by overbank facies $\left(87{ }^{14} \mathrm{C}\right.$ dates), $d$ - peat (709 ${ }^{14} \mathrm{C}$ dates), e-deep seated landslides $\left(69-{ }^{14} \mathrm{C}\right.$ dates from Polish Flysch Carpathians), $f$ - minerogenic horizons within landslide $\left(98{ }^{14} \mathrm{C}\right.$ dates, from Polish Flysch Carpathians), as rectangles are marked phases of debris flows in Tatra Mts; a dashed rectangle was used for period with rare minerogenic inserts within the sequences of lacustrine sediments, $g$ - speleothems (98 ${ }^{14} \mathrm{C}$ dates), $h$ - calcareous tufa ( $100{ }^{14} \mathrm{C}$ dates). There are added 100-yr running averages for speleothems and tufa curves, because these data have got the highest uncertainty due to reservoir effect). The curve of 400 subfossil oak trunks dated by dendrochronological method by $M$. Krapiec is presented in diagram (i). Episodes of frequent floods indicated on the base of floating chronologies are marked in the same figure by grey rectangles. High water levels in Lake Gościąz are marked in figure (j) - phases 9500-8500 and 2500-2000 cal BP, as the most clear, are marked by rectangle; and phase 5000-4100 - by triangle as a less clear, especially at the beginning. Below, information about changes in temperature, precipitation and stratigraphy, summarized on the base of stratigraphy for numerous investigated sites, palynological diagrams and palaeohydrological reconstructions (see text), is presented. The proposed boundaries are indicated by vertical lines. Used abbreviations: YD - Younger Dryas, PB - Preboreal, BO - Boreal, AT - Atlantic (divided into 5 subzones), $S B$ - Subboreal (divided into 2 sub-zones), $S A$ - Subatlantic (divided into 3 sub-zones). 
ing in the Allerød and the permafrost degradation (1335012650 cal BP). Analogous stage of mineral material deposition in peat-bogs is visible ca. 12000-11700 cal BP, in the decline of the Younger Dryas (Margielewski, 2001; 2006; (Ed.) 2003). The next group of minerogenic horizons ages is located between 10,200 and $9600 \mathrm{cal} \mathrm{BP,}$ while new, deep landslides formed ca. $9500 \mathrm{cal}$ BP and their development lasted till $9100 \mathrm{cal}$ BP. New landslides formed also in periods 7800-7600 and 6900-6600 cal BP. A distinct concentration of the landslides' and minerogenic horizons' ages is observable at ca. 5700-5500 cal $\mathrm{BP}$, in the upper Atlantic (AT4/AT5), during strong climate moistening at that time (Margielewski, 2006). Slightly lower increase of mass movement activity is noticed also ca. 4100 cal BP and 3700 cal BP. The younger distinct concentration of ages of landslides and minerogenic horizons is marked at ca. $2800 \mathrm{cal} \mathrm{BP}$ at the beginning of the Subatlantic and had its maximum at ca. 2400-1900 cal BP. The next aggregation of ages occurs ca. 1400-1200 cal BP, whereas the series of ages of mass movements recorded since ca. $1000 \mathrm{cal}$ BP may coincide with some moistening and the beginning of intensive human activity. The youngest concentration of ages at ca. 700-500 cal yrs BP is connected with the beginning of the Little Ice Age. Lichenometric dating of Carpathian landslides indicates also the intensification of mass movements in the following periods: AD 1609-1610, 17051720 and 1829-1833 (Bajgier-Kowalska, 2008).

\section{Debris flows in the Tatra Mts. (Fig. 2f, rectangles)}

The particularly strong intensification of the debris flows (reflected as high-energetic sediments' horizons in several lakes) indirectly dated at ca. $8300 \pm 120$ BP (95509000 cal yrs BP) (Kotarba and Baumgart-Kotarba, 1997) was connected with the strong climate moistening due to heavy downpours. Rare minerogenic inserts within the sequences of lacustrine sediments were dated also at ca. 8600-6600 cal BP. The next phase of debris flows' intensification is marked at ca. 5900-5600 cal BP, as well as at ca. 4900-3400 cal BP and 2700-1800 cal BP. The best recorded period of intensification of slope processes in the Tatra Mts. is the Little Ice Age (AD 1400-1860) (Kotarba, 2006). The following activation periods were dated by lichenometric and ${ }^{210} \mathrm{~Pb}$ methods and also by historical sources: rockfalls during periods of $\mathrm{AD}$ 1676-1700, 1751-1775, and debris flow during periods of 1810-1835, 1843-1852, 1860-1880, 1900-1905 (Kotarba, 1995; 1996 and 2006).

\section{Speleothems (Fig. 2g)}

Frequency distribution of ${ }^{14} \mathrm{C}$ dates (PDF curve) indicates the presence of a few phases of intense deposition of speleothems in caves. First sedimentation of speleothems appears in the Allerød (13500-12600 cal BP), after a glacial period almost without any presence of speleothems. There is a visible break in sedimentation during
Younger Dryas, and the next period $11300-8500$ cal BP is represented only by a few dates. A distinct rise of the number of speleothems, which appears in the period 8400-7300 cal BP, indicates a climate warming. There are also visible culminations in the periods of 5700-4800, 4000-3200, 2800-2200, 1500-1200 and 800-500 cal BP. Undoubtedly these periods were characterised by an increase of water soaking and climate warming. Relatively higher values of PDF curve for the last three thousand years could result from the obvious fact that there is a higher probability of preservation of younger speleothems.

\section{Calcareous tufas (Fig. 2h)}

The PDF curve for tufa samples well reflects the changes in temperature during the Holocene, with culmination for the Mesoholocene, although variable hydrodynamic conditions in Cracow-Wieluń Upland and Lublin Upland have also influenced its shape (Dobrowolski et al., 1999).

The initial accumulation phase is visible at the end of the Allerød and reaches culmination for the border between Younger Dryas and Holocene. The next, probably both warm and humid, episodes appear ca. 10400-10200 and $9700-9500 \mathrm{cal} \mathrm{BP}$. It is possible that these two peaks indicate the beginning and the end of relatively warm and humid phase. There are rare ${ }^{14} \mathrm{C}$ dates for the humid, but rather cooler period of 9500-8500 cal BP. The next part of the Mesoholocene is characterised by several distinct culminations. The maximum of PDF curve encompasses the period 6600-6200 cal BP, which is the main warm period. Subsequently, the PDF curve decreases and reaches minimum for the period of 4800-3900 cal BP, which was wet at the beginning and cold. More intense tufa sedimentation appears three times more: $3700-3000$, 2200-1700 (warmer phase), and 700-500 cal BP.

\section{Subfossil oaks from alluvial deposits (Figs. 2i and 3)}

A diagram based on 400 absolutely dated dendrochronological sequences from the last 3800 years permitted the identification of periods with prevailing seeding and felling of trees on the flood plains, interpreted respectively as drier periods or more humid ones characterised by frequent floods (Krąpiec, 1992; 1998; 2001). The oldest distinct phase of felling trees which grew in the period 3750-3500 calendar years BP took place in the years 3575-3425 calendar years BP. Between 3425 and 1600 calendar years BP successive phases of seeding and felling of the oak trees growing on the flood plains were noted. It is possible to distinguish, particularly in the preRoman period, the time intervals with more seeding (drier periods): $2975-2925,2825-2750$ and 2425-2350 calendar years BP; as well as more humid periods, with more floods: $3250-3225,2850-2800$ and 2700-2650 calendar years BP. From ca 2350 to 1625 (1600) calendar years $\mathrm{BP}$ there is lack of distinct maxima on the diagram, ex- 
cept the last 200 years, when felling was predominating above seeding. After 1600 (1625) calendar years BP a surge in seeding of oaks in the river valleys was noted, which could be interpreted as a drying of the climate, enabling the trees to enter the flood plains. About 1500 calendar years BP next humid period started, which lasted for about 150 years. The trunks from that period are most often represented among the collection from the last 3800 years, proving the intensity and repetitiveness of the floods. In the sixth century significantly quieter period commenced, with culminations of seeding and growth of young trees (germination phases) noted in the periods $1225-1025,825-775$ and $650-575$ calendar years BP, and the increase of felling in the more humid periods: 1000$825,750-675$ and 500-450 calendar years BP. Because dendrochronological data have a higher resolution than the frequency distribution of ${ }^{14} \mathrm{C}$ dates presented in Fig. 2, they are presented also in separate figure - Fig. 3 . Indicated humid and dry periods are marked by rectangles at the bottom part of this figure. PDF for fluvial data was added in the upper part of Fig. 3 for comparison. A good correlation of dendro-data with location of chronozones boundaries is well visible. Each boundary falls at the beginning of a wetter phase.

Besides the chronologies absolutely dated using dendrochronology, floating chronologies were also compiled. The latter were dated using the wiggle-matching method
(Krapiec, 2001). They indicate the episodes of frequent floods (felling oaks) in the periods: 4000-3850, 51805100 and 8400-8250 calendar years BP, which correlate well with the dated positions of the flood sediments (Starkel, 2002 and 2003). The mentioned episodes of frequent floods are marked in Fig. $2 \mathrm{i}$ by grey rectangles.

\section{Lake water level changes (Fig. 2j)}

The closed and not transfluent lake basins deliver valuable records of lake water level fluctuations during the Holocene. In her review paper Ralska-Jasiewiczowa (1989) mentioned several lake level, but in the summarising paper, only three lake transgressions were mentioned (Ralska-Jasiewiczowa and Latałowa, 1996). On the basis of facial change in sediment cores some authors have distinguished several other phases (Wojciechowski, 1999). The reconstructions for Lake Gościąż accompanied by the varve chronology seem to be the most reliable. In the annually laminated sediments of Lake Gościąż only two distinct lake transgressions are clearly recorded - about 9500-8500 and 2500-2000 cal BP (Starkel et al., 1998; Ralska-Jasiewiczowa et al., 1998). The second one is also well documented in the Biskupin archaeological site, flooded during the Late-Bronze age (Niewiarowski et al., 1995). Less clear is the phase about 5000-4100 BP (Starkel et al., 1998).

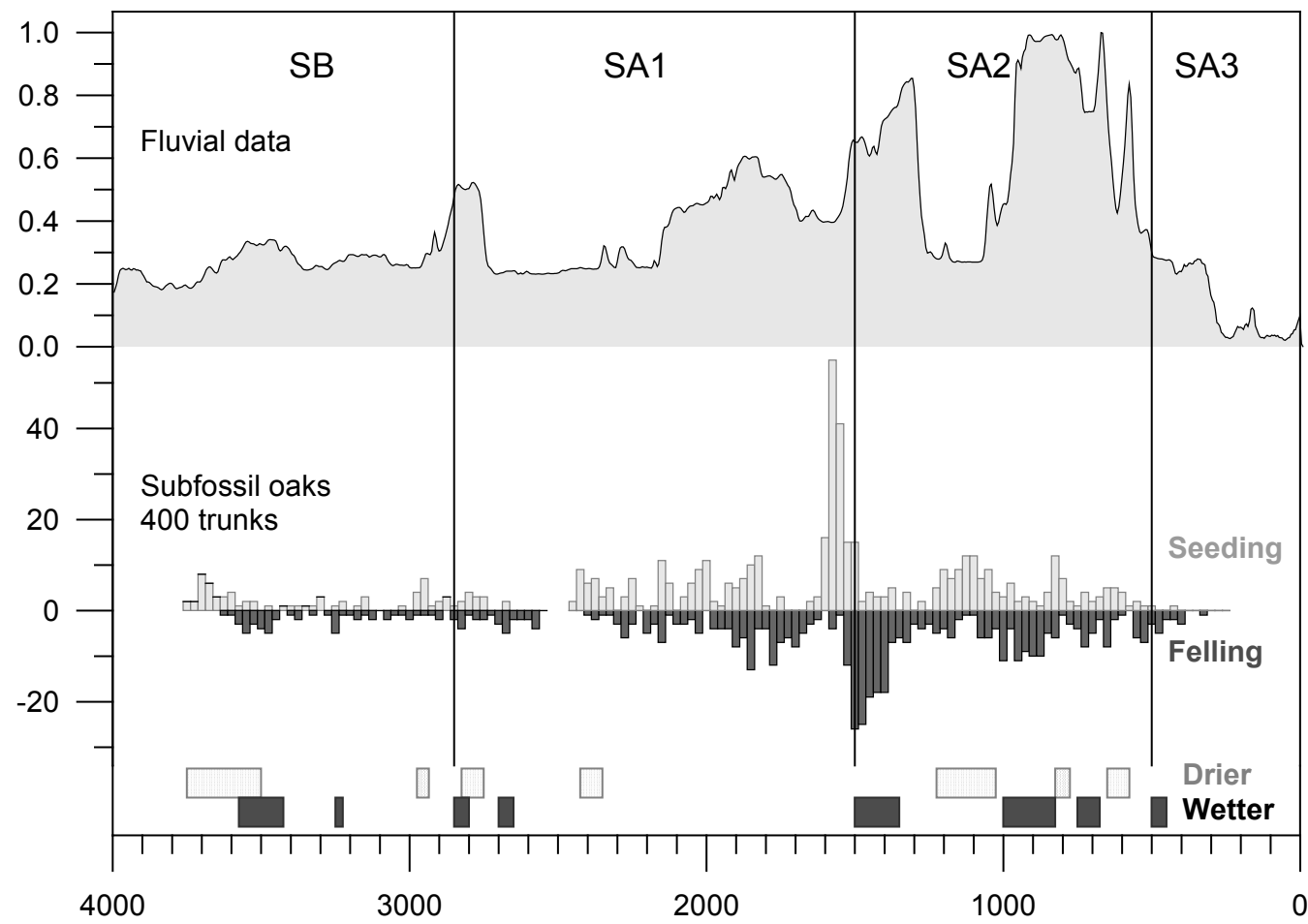

Fig. 3. Diagram based on 400 absolutely dated dendrochronological sequences from the last 3800 years. Periods with prevailing seeding and felling of trees on the flood plains could be interpreted respectively as drier periods or more humid ones characterised by frequent floods. Identified drier and wetter phases are marked at the bottom part of the figure. In the upper part of the figure PDF for fluvial data is presented for comparison. Location of chronozones boundaries is in accordance with the beginning of wetter phases. 
All these three phases are well correlated with phases recorded in fluvial and colluvial types of sediments. The phases proposed by other authors (see above) are not recorded, what may be explained by a different character and frequency of heavy rainfalls which probably have been restricted to the hilly areas of Southern Poland.

At the bottom of the Fig. 2 compiled information about temperature, precipitation and stratigraphy is presented. The compilation is based on the stratigraphy for numerous investigated sites, palynological diagrams and palaeohydrological reconstructions (Berglund et al., 1996; Ralska-Jasiewiczowa, 1989; Ralska-Jasiewiczowa and Latałowa, 1996; Ralska-Jasiewiczowa et al., 2004; Starkel (Ed.), 1990 and 1991; Nalepka, 2005 and references cited therein). The presented records and PDF curves from various facies and sediments, even if not consisting of a sufficient number of data in every group from statistical point of view (some gaps of PDF curves could be connected with a too small number of data in particular sets), show a relatively high temporal agreement in the reflection of changes in temperature and humidity during the Holocene on the Polish territory. The results are summarised in Table 1 which provides a complete list of all defined phases and their characteristic features.

\section{DISCUSSION AND CONCLUSIONS}

The authors do not discuss the uncertainties for particular boundaries. It seems acceptable to assume of the magnitude of uncertainty between 50 and 100 years at a present state of the study. These numbers are in accordance with the width of the time intervals of the growing slope of the peaks used to defining the boundaries.

\section{Conclusions on climatostratigraphy based on the PDF of radiocarbon dates from the Polish territory}

The curves presented in Fig. 2 confirm the previous concept of the fluctuation of temperature and hydrological regime based on selected localities, like Lake Gościąż and a sequence of alluvial cuts and fills in the upper Vistula basin. Several wetter and cooler phases recorded in different sediment facies and in vegetation changes are characterised by frequent extreme precipitation of various types: heavy downpours, continuous rains and long-term rainy seasons (Starkel, 2003 and 2006b). Each of these types is represented by a different group of records: heavy downpours expressed in intercalation of sandy or silty layers present in alluvial fans and in debris flows above timberline; continuous rains reflected in floods, channel avulsions in wide valley floors and landsliding; the long rainy seasons in rising of lake levels and formation of deep rocky landslides in the Carpathians. The temperature rise, especially during the Mesoholocene, is reflected in the growth of speleothems and formation of calcareous tufa as well as in the expansion of termophilous plants (see Table 1).
The most significant difference between alternating wetter phases and the relatively drier ones is based on the frequency of extreme events and their intensity which is much higher for the wetter phases. The best example of this system is the Little Ice Age for which there are detailed records of climatic parameters and for which reflection in plant communities and different facies of sediment is observed (Grove, 1988; Kotarba, 1995; 2006). Another important feature of these events is their grouping in clusters, several years or even several decades long (Starkel, 2002; 2006a). Similar clusters are recorded at Podgrodzie alluvial fan locality from early Holocene at 9500-8500 cal BP where among 100 events about 11 clusters were recorded (Starkel, 1999; Czyżowska, 1997).

\section{Types of climato-chronostratigraphic boundaries for the Holocene on the Polish territory}

The enclosed Fig. 2 presents the suggested, revised model of the Holocene climato-chronostratigraphy for the Polish territory, based on the different indicators during successive, chronostratigraphic phases and boundaries separating them (see also Table 1 ).

The boundaries between various phases of the Holocene are controlled either by changes in temperature or in humidity and hydrological regime (Fig. 2, bottom part). The leading factor in Quaternary stratigraphy is the changes in temperature which build also the skeleton of the Holocene chronostratigraphy (Eo- Meso- and NeoHolocene - cf. Firbas, 1954 and Neustadt, 1957).

The second order subdivision is connected with variations in humidity and frequency of extreme rainfalls. The wetter phases have usually very distinct start and then gradually the indicators of humidity become more equivocal.

Among the most discussed problems is the position of two boundaries: Eo-Mesoholocene and MesoNeoholocene considering both temperature and humidity factors. The first chrono-climatostratigraphic boundary we put at 9600 cal BP, although in fact it has a two-fold character. At about 9600 cal BP together with a rapid melting of Laurentide ice sheet a freeway was created for westerlies and humid air masses expanded over Europe and Siberia (Starkel, 1999), bringing heavy rains and floods. Simultaneously this change was accompanied by expansion of Atlantic forest species. However, the real start of a warm period reflected in calcareous precipitation and reign of Quercetum mixtum followed one millennium later (Ralska-Jasiewiczowa et al., 2004).

The border between Meso- and Neoholocene has also a complex character. In the present study it is placed at about 4850 cal BP. But even earlier, at about $5600 \mathrm{cal} \mathrm{BP}$ a first distinct cooling and wetter phase can be observed, reflected in avulsions of river channels, formation of new landslides - being synchronous with first post-optimum phase of glacial advances in the Alps. However several centuries later a general rebuilding of ecosystems initiated by rise of humidity and cooling has started, and was 
Table 1. Successive, chronostratigraphic phases and boundaries separating them with information about changes based on the shape of PDFs and other environmental indicators.

\begin{tabular}{|c|c|c|c|c|}
\hline Cal BP & $\begin{array}{l}\text { Phases and } \\
\text { boundaries }\end{array}$ & Observed features of PDF curves & Climate & $\begin{array}{l}\text { Vegetation changes and human } \\
\text { impact *) }\end{array}$ \\
\hline $14,000-12,650$ & Allerød & Rise for peat, fluvial deposits, landslides & & $\begin{array}{l}\text { Forested landscape. Birch-pine } \\
\text { (Betula-Pinus) and pine-birch (Pinus- } \\
\text { Betula) forests. }\end{array}$ \\
\hline 12,650 & Transition & $\begin{array}{l}\text { Distinct decline of PDF curve for peat, } \\
\text { fluvial data and speleothems }\end{array}$ & Rapid cooling & \multirow{3}{*}{$\begin{array}{l}\text { Diminishing of forests landscape, } \\
\text { opening landscape. } \\
\text { Spread of heliophilous herbs (Artemi- } \\
\text { sia, Chenopodiaceae) and grases } \\
\text { (Poaceae) communities. Mainly open } \\
\text { landscape with heliophilous shrubs } \\
\text { juniper (Juniperus), sea-buckthorn } \\
\text { (Hippophaë), scattered larch (Larix) } \\
\text { and scattered pine (Pinus) and birch } \\
\text { (Betula) open woods. Tundra with } \\
\text { dwarf birch (Betula nana) on the wet } \\
\text { habitats. }\end{array}$} \\
\hline $12,650-11,500$ & Younger Dryas & $\begin{array}{l}\text { Decline for peat, fluvial deposits, lack of } \\
\text { speleothems, rise of minerogenic hori- } \\
\text { zons on landslide }\end{array}$ & & \\
\hline 11,500 & $\begin{array}{l}\text { Younger Dryas } \\
\text { - Eoholocene } \\
\text { transition. } \\
\text { Boundary of } \\
\text { first order }\end{array}$ & $\begin{array}{l}\text { Slow rise for fluvial data and peat (envi- } \\
\text { ronment needed time to register this } \\
\text { boundary in sediments) }\end{array}$ & $\begin{array}{l}\text { Rapid warming, rise of lake } \\
\text { water level }\end{array}$ & \\
\hline $11,500-10,200$ & PB & $\begin{array}{l}\text { High frequency of abundance of palaeo- } \\
\text { channels, first Holocene landslides }\end{array}$ & $\begin{array}{l}\text { Warming, expansion of } \\
\text { forest and peatbogs, abun- } \\
\text { dance of large paleochan- } \\
\text { nels }\end{array}$ & \multirow{7}{*}{$\begin{array}{l}\text { Expansion of birch and pine forests } \\
\text { entering of first deciduous trees (elm } \\
\text { (Ulmus) and shrubs hazel (Corylus)) }\end{array}$} \\
\hline 10,200 & $\begin{array}{l}\text { PB/BO bound- } \\
\text { ary }\end{array}$ & $\begin{array}{l}\text { Peak of peat formation, peat/soil covered } \\
\text { by overbank facies and calcareous tufa, } \\
\text { decline for abundance of palaeochannels }\end{array}$ & & \\
\hline $10,200-9600$ & BO & $\begin{array}{l}\text { Decline of fluvial activity, peat formation } \\
\text { and tufa, rise of speleothems }\end{array}$ & & \\
\hline 9600 & $\begin{array}{l}\text { Eo-Meso- } \\
\text { Holocene } \\
\text { transition }\end{array}$ & $\begin{array}{l}\text { Distinct rise of fluvial deposits, peat } \\
\text { formation, landslides, debris flows, } \\
\text { calcareous tufa }\end{array}$ & Start of humid phase & \\
\hline $9600-8400$ & AT1 & $\begin{array}{l}\text { Fluvial deposits, peat formation, land- } \\
\text { slides, debris flows }\end{array}$ & $\begin{array}{l}\text { First phase of high frequen- } \\
\text { cy of extreme events; rise of } \\
\text { lake levels }\end{array}$ & \\
\hline 8400 & AT1/AT2 & $\begin{array}{l}\text { Beginning of high deposition of speleo- } \\
\text { thems and calcareous tufa }\end{array}$ & $\begin{array}{l}\text { End of humid phase, rise in } \\
\text { temperature }\end{array}$ & \\
\hline $8400-7700$ & AT2 & Peaks of tufa and speleothems & Warm and drier phase & \\
\hline
\end{tabular}


Table 1. Continuation

\begin{tabular}{|c|c|c|c|c|}
\hline Cal BP & $\begin{array}{l}\text { Phases and } \\
\text { boundaries }\end{array}$ & Observed features of PDF curves & Climate & $\begin{array}{l}\text { Vegetation changes and human } \\
\text { impact *) }\end{array}$ \\
\hline 7700 & AT2/AT3 & $\begin{array}{l}\text { Peaks of fluvial data, peat, tufa and } \\
\text { speleothems }\end{array}$ & $\begin{array}{l}\text { Change in vegetation and } \\
\text { fluvial regime, short rise in } \\
\text { frequency of extremes }\end{array}$ & \multirow{4}{*}{$\begin{array}{l}\text { Intensive changes in forest composi- } \\
\text { tion - diminishing of deciduous mixed } \\
\text { forests with ash (Ulmus), lime (Tilia), } \\
\text { ash (Fraxinus). }\end{array}$} \\
\hline $7700-6400$ & AT3 & $\begin{array}{l}\text { Low fluvial activity and peat growth; } \\
\text { landslides }\end{array}$ & Next warm phase & \\
\hline 6400 & AT3/AT4 & $\begin{array}{l}\text { Distinct rise of peat growth and fluvial } \\
\text { activity }\end{array}$ & Rise of precipitation & \\
\hline $6400-5600$ & AT4 & $\begin{array}{l}\text { Rise of peat growth, peak of speleothems } \\
\text { and tufa, rise of landslides, minerogenic } \\
\text { horizons }\end{array}$ & Humid phase & \\
\hline 5600 & AT4/AT5 & $\begin{array}{l}\text { Rise in fluvial activity, tufa, peak in } \\
\text { minerogenic horizons, landslide activity }\end{array}$ & Rise of precipitation & \multirow{2}{*}{$\begin{array}{l}\text { Progressive land-occupation by } \\
\text { Neolithic farmers. Entering of human } \\
\text { settlements, first agriculture. Entering } \\
\text { of newcomers trees (late-migrants } \\
\text { spruce (Picea), hornbeam (Carpinus), } \\
\text { beech (Fagus), fir (Abies) }\end{array}$} \\
\hline $5600-4850$ & AT5 & $\begin{array}{l}\text { Low fluvial activity and landslides, high } \\
\text { speleothems, higher peat growth }\end{array}$ & Warm phase & \\
\hline 4850 & $\begin{array}{l}\text { Meso-Neo- } \\
\text { Holocene } \\
\text { transition }\end{array}$ & Decline in tufa, peak of peat growth & $\begin{array}{l}\text { Distinct cooling, rise in } \\
\text { humidity }\end{array}$ & \multirow{2}{*}{$\begin{array}{l}\text { Diminishing oak (Quercus) and hazel } \\
\text { (Corylus) in the forests composition }\end{array}$} \\
\hline $4850-3700$ & SB1 & Deposition of tufa and speleothems & $\begin{array}{l}\text { Gradual decline in humidity, } \\
\text { decline of temperature }\end{array}$ & \\
\hline 3700 & SB1/SB2 & $\begin{array}{l}\text { Beginning of rise in fluvial activity, peak } \\
\text { of speleothems and tufa }\end{array}$ & Start of next warmer phase & \multirow{4}{*}{$\begin{array}{l}\text { Forest regression, expansion } 0 \\
\text { agriculture. }\end{array}$} \\
\hline $3700-2850$ & SB2 & $\begin{array}{l}\text { Rise and later decline in fluvial activity; } \\
\text { deposition of tufa and speleothems }\end{array}$ & Warm phase & \\
\hline 2850 & SB/SA & $\begin{array}{l}\text { Episode of changes in peat growth, } \\
\text { fluvial activity, frequent landslides, spele- } \\
\text { othems }\end{array}$ & Short rise in humidity & \\
\hline $2850-1500$ & SA1 & $\begin{array}{l}\text { Higher fluvial activity, peak for peat/soil } \\
\text { covered by overbank facies, landslides } \\
\text { and tufa }\end{array}$ & $\begin{array}{l}\text { Cooler period with high lake } \\
\text { level, later turn to warmer } \\
\text { period and start of intensive } \\
\text { soil erosion }\end{array}$ & \\
\hline 1500 & SA1/SA2 & $\begin{array}{l}\text { Peak of fluvial activity, peat, landslides } \\
\text { and subfossil oaks }\end{array}$ & Short cooling & \multirow{4}{*}{$\begin{array}{l}\text { Anthropogenic landscape, forests } \\
\text { diminishing }\end{array}$} \\
\hline $1500-500$ & SA2 & $\begin{array}{l}\text { Intensive fluvial activity (subfossil oaks), } \\
\text { peak of landslides and tufa, later decline } \\
\text { of fluvial activity, peat and landslides }\end{array}$ & Gradual warming & \\
\hline 500 & SA2/SA3 & & Beginning of Little Ice Age & \\
\hline 500-present & SA3 & Small number of dates for this period & & \\
\hline
\end{tabular}

*) only distinct boundaries between different vegetation landscapes are marked by horizontal lines in the last column. 
recorded in rise of groundwater level and transitional descend of Picea excelsa to lower elevations, later followed by expansion of Fagus and Abies (Gil et al., 1974, Starkel, 1995). Comparison with the INTIMATE Event Stratigraphy and previous chronostratigraphic divisions.

In 1995 the INTIMATE project was initiated as a core project of the INQUA Palaeoclimate Commission which has a primary goal to establish timing of palaeoenvironmental events in the North Atlantic region during the Last Termination. A protocol for time-stratigraphic correlation over time interval 30-8 ka BP has recently been published (Hoek et al., 2008, Lowe et al., 2008, Blockley et al., 2012). The INTIMATE Event Stratigraphy scheme was proposed as a standard against which regional stratigraphies should be compared to look for synchronicity (or asynchronicity) of comparable events. It is based on the new NGRIP isotopic record and associated Greenland Ice Core Chronology 2005 (GICC05) (Rasmussen et al., 2006).

There is an excellent agreement between proposed values of the boundaries Allerød/Younger Dryas and Younger Dryas/Preboreal and these boundaries recorded in Gościąż Lake sediments (Table 2). The boundaries of Allerød/Younger Dryas and Younger Dryas/Preboreal for Poland and Greenland ice core seem to be shifted (boundaries for Poland are slightly delayed), but if we take into account the uncertainty of boundaries values for both localities then from the statistical point of view they are in concordance, what could be confirmed by simple tests:

$$
\frac{|12846-12650|}{\sqrt{100^{2}+\left(\frac{138}{2}\right)^{2}}}=\frac{196}{121.5}<2
$$

and

$$
\frac{|11653-11500|}{100^{2}+\left(\frac{99}{2}\right)^{2}}=\frac{153}{111.6}<2
$$

These tests confirm that differences between values of boundaries for Poland and Greenland are less than two standard deviations.

A much more complicated situation is observed for the chronostratigraphic boundaries during the Holocene. As it was mentioned earlier the sequence of fluctuations reflected in the glacial records of higher latitudes (e.g., Bond et al., 2001; Mayewski et al., 2004), suggested to be representative on the global scale, do not coincide with glacial advance phases and lake level fluctuations in the European belt between $43^{\circ}$ and $50^{\circ}$ of northern latitude (Hormes et al., 2001; Magny et al., 2003). These zonal latitudinal differences have been explained by changes in westerlies activity. The Carpathians and southern Poland are located in this zone as well as in the deciduous forest belt of Eastern Europe. That jet stream route with humid air masses was blocked in the Early Holocene before the extensive Laurentide ice sheet has melted (Starkel, 1999). In the following millennia the wetter phases with frequent extreme rainfalls and advances of arctic air masses appear mainly in the same centuries in the Alps and the Carpathians as well as on their northern foreland. But this does

Table 2. Proposed boundaries of chronozones expressed in calendar years Before Present (before AD 1950) for the Polish territory and comparison with previous divisions and also boundaries recorded in Gościąż Lake and Greenland ice core. For NGRIP boundaries, maximum counting errors are

\begin{tabular}{|c|c|c|c|c|c|c|}
\hline & $\begin{array}{l}\text { This } \\
\text { study }\end{array}$ & $\begin{array}{c}\text { Starkel, } 1977,1991 \text { after } \\
\text { calibration } \\
68.2 \% \text { conf. int. } \\
\end{array}$ & $\begin{array}{l}\text { Michczyńska et al., } \\
\left.2008^{*}\right)\end{array}$ & $\begin{array}{l}\text { Walanus and Nalepka, } \\
\left.2004,2010^{* *}\right)\end{array}$ & $\begin{array}{c}\text { Gościąż } \\
\text { Kuc et al., } \\
1998\end{array}$ & $\begin{array}{c}\text { NGRIP } \\
\text { Love et al., } \\
2008\end{array}$ \\
\hline $\mathrm{AL} / \mathrm{YD}$ & 12650 & $13770-13500$ & 12650 & & 12650 & $12846(138)$ \\
\hline YD/PB & 11500 & $12400-11750$ & 11500 & 11550 & 11500 & $11653(99)$ \\
\hline PB/BO & 10200 & $10650-10290$ & 10200 & 10100 & & \\
\hline BO/AT & 9600 & $9520-9300$ & 9500 & 8850 & & \\
\hline AT1/AT2 & 8400 & $8590-8400$ & 8450 & & & \\
\hline AT2/AT3 & 7700 & $7480-7420$ & 7500 & & & \\
\hline AT3/AT4 & 6400 & $6980-6720$ & 6500 & & & \\
\hline AT4/AT5 & 5600 & $5900-5640$ & (AT4/SB1) 5600 & 5750 & & \\
\hline AT5/SB1 & 4850 & $4860-4580$ & (SB1/SB2) 4850 & & & \\
\hline SB1/SB2 & 3750 & & & & & \\
\hline $\mathrm{SB} / \mathrm{SA}$ & 2850 & $3070-2780$ & 2750 & 2550 & & \\
\hline SA1/SA2 & 1500 & $2110-1830$ & 2000 & & & \\
\hline SA2/SA3 & 500 & $650-460$ & 500 & & & \\
\hline
\end{tabular}
given in parenthesis. 
not prove that all of these climatic changes are of the global or hemisphere extent like Little Ice Age or shorter events recorded about 9300,8200 or 2750 cal BP event (cf. Macklin et al., 2006).

The presented proposal of climatostratigraphic chronological division of the Holocene is based on the records delivered by various facies of sediment from the Polish territory in which changes in hydrological regime are especially well expressed. Their characteristic feature are wetter phases with relatively sharp beginning which alternate with more mild and drier phases. These phases are superimposed on the long-term temperature fluctuations controlled by solar radiation.

The presented results are the summary based on previous comprehensive reports for selected types of sedimentary environments and provide an introduction to the next step to precise Holocene chronostratigraphy. Research is still in progress. Proposed calendar values of chronozones boundaries will be verified on the basis of literature studies and analysis of ${ }^{14} \mathrm{C}$ dates from single sites. Especially, the set of dates for peat samples is a potential source of subsequent information. As the most numerous set it gives an opportunity to divide into subsets for investigation of various factors. Also information about the order of the deposits (peat over lacustrine deposits and lacustrine deposits over peat) could be helpful in precise evaluation of boundaries of the chronozones.

\section{ACKNOWLEDGEMENTS}

The presented problem was discussed in recent years by the team of Palaeoclimatic-Palaeohydrological Section of the Committee for Quaternary of the Polish Academy of Sciences, Commission on Quaternary Palaeogeography Polish Academy of Art and Sciences and the team of GADAM Centre of Excellence. The final stage of the manuscript was elaborated thanks to the financial support through the grant no. N N306 034040 (Polish National Science Centre grant "Application of statistical methods to reconstruct climate change on the Polish territory in the Late Glacial and Holocene") and partly by the Institute of Nature Conservation PAS and W. Szafer Institute of Botany PAS statutory funds. The authors would like to express their deepest gratitude to the reviewers - Prof. Helena Hercman and the anonymous one for their numerous valuable comments and suggestions, which were helpful in improving the paper.

\section{REFERENCES}

Aitchison TC, Leese M, Michczyńska DJ, Mook WG, Otlet RL, Ottaway BS, Pazdur MF, van der Plicht J, Reimer PR, Scott MS, Stuiver M and Weninger B, 1989. A comparison of methods used for the calibration of radiocarbon dates. Radiocarbon 31(3): 846864 .

Alexandrowicz SW, 1987. Analiza malakologiczna w badaniach osadów czwartorzędowych (Malacological analysis in Quaternary sediments research). Kwartalnik AGH, Geologia 12(1-2): 3-240 (in Polish).
Alexandrowicz SW, 1996. Stages of increased mass movements in the Carpathians during the Holocene. Kwartalnik AGH, Geologia 22(3): 223-262 (in Polish with English summary).

Alexandrowicz SW, 1997a. Holocene dated landslides in the Polish Carpathians. Palaeoclimate Research 19: 75-83.

Alexandrowicz WP, 1997b. Malakofauna osadów czwartorzędowych i zmiany środowiska naturalnego Podhala w młodszym vistulianie i holocenie (Malacofauna of Quaternary sediments and changes of natura environmental of Podhale in younger Vistulian and Holocene). Folia Quaternaria 68: 7-132 (in Polish).

Alexandrowicz WP, 2001. Late Vistulian and Holocene molluscan assemblages from calcareous tufa at Ostrysz Hill (Podhale Basin). Folia Malacologica 9(3): 159-169.

Alexandrowicz WP, 2004. Molluscan assemblages of Late Glacial and Holocene calcareous tufas in Southern Poland. Folia Quaternaria 75, 3-309.

Alexandrowicz WP, 2009. Malacostartigraphy of Vistulian and Holocene in Poland. Studia Quaternaria 26: 55-63.

Arnold JR and Libby WF, 1951. Radiocarbon dates. Science 113(2927): 111-120, DOI 10.1126/science.113.2927.111.

Bajgier-Kowalska M, 2008. Lichenometric dating of landslide episodes in the Western part of the Polish Flysch Carpathians. Catena 72(2): 224-234, DOI 10.1016/j.catena.2007.05.005.

Baumgart-Kotarba M and Kotarba A, 1993. Late Glacial and Holocene lacustrine sediments of the Lake Czarny Staw Gąsienicowy in the Tatra Mountains. Dokumentacja Geograficzna 4-5: 9-30 (in Polish with English summary).

Baumgart-Kotarba M, Kotarba A and Wachniew P, 1993. Young Holocene lacustrine sediments from Lake Morskie Oko in the High Tatra Mountains and their datings by use ${ }^{210} \mathrm{~Pb}$ and ${ }^{14} \mathrm{C}$. Dokumentacja Geograficzna 4-5: 45-61 (in Polish with English summary).

Becker B, 1982. Dendrochronologie und Paläoökologie subfossiler Baumstämme aus Flussablagerungen (Paleoecology and dendrochronology of subfossil logs from river sediments). Mitteilungen der Kommission für Quarterforschung 5: 1-121 (in German).

Berglund BE, Birks HJB, Ralska-Jasiewiczowa M, and Wright HE Jr. Eds., 1996. Palaeohydrological events during the last 15,000 years: Regional Syntheis of Palaeoecological Studies of Lakes and Mires in Europe. Chichester, New York, Brisbane, Toronto, Singapore , J. Wiley \& Sons Ltd.: 764 pp.

Birks HJB, 1979. Numerical methods for the zonation and correlation of biostratigraphical data. In: Berglund BE, Ed., Palaeohydrological changes in the temperate zone in the last 15.000 years. IGCP 158 B. Lake and mire environments. Project Guide 1: 99-123.

Birks HJB, 1986. Numerical zonation, comparison and correlation of Quaternary pollen-stratigraphical data. In: Berglund BE, Ed., Handbook of Holocene Palaeoecology and Palaeohydrology. Chichester, New York, J. Wiley \& Sons Ltd.: 743-774.

Blockley SPE, Lane CS Hardiman M, Rasmussen SO, Seierstad IK, Steffensen JP Svensson A, Lotter AF, Turney CSM, Bronk Ramsey $\mathrm{C}$ and INTIMATE members, 2012. Synchronisation of palaeoenvironmental records over the last 60,000 years, and an extended INTIMATE1 event stratigraphy to 48,000 b2k. Quaternary Science Reviews 36: 2-10, DOI 10.1016/j.quascirev.2011.09.017.

Blytt A, 1882. Die Theorie der wechselnden kontinentalen und insularen Klimate (The theory of changes of continental and insular climate). Leipzig, Botanische Jahrbücher 2: 1-50 (in German).

Bond GG, Kromer B, Beer J, Muscheler R, Evans M, Showers W, Hoffman S, Lotti-Bond R, Hajdas I and Bonani G, 2001. Persistent solar influence on North Atlantic Climate During the Holocene. Science 294: 2130-2136, DOI 10.1126/science.1065680.

Bronk Ramsey C, 1995. Radiocarbon calibration and analysis of stratigraphy: the OxCal program. Radiocarbon 37(2): 425-430.

Bronk Ramsey C, 2001. Development of the radiocarbon calibration program. Radiocarbon 43(2A): 355-63.

Bronk Ramsey C, 2006. OxCal program v 4.0 [software and documentation]. http://c14.arch.ox.ac.uk/oxcal/hlp_contents. html.

Brunnacker K, 1978. Der Niederrhein im Holozän (The Lower Rhine region in the Holocene). Fortschritte in der Geologie von Rheinland und Westfalen 28: 399-440 (in German). 
Buck CE, Kenworthy JB, Litton CD and Smith AFM, 1991. Combining archaeological and radiocarbon information: a Bayesian approach to calibration. Antiquity 65(249): 808-821.

Czyżowska E, 1997. Zapis zdarzeń powodziowych na pograniczu boreału i atlantyku w osadach stożka napływowego w Podgrodziu (Record of flood events on the border of Boreal and the Atlantic in sediments of the alluvial fan in Podgrodzie). IGiPZ PAN Warszawa. Dokumentacja Geograficzna 5 (in Polish).

Delorme A and Leuschner H-H, 1983. Dendrochronologische Befunde zur jüngeren Flussgeschichte von Main, Fulda und Oker (Dendrochronological findings in younger history of the river Main, Fulda and Oker). Eiszeitalter und Gegenwart 33: 45-57 (in German).

Dobrowolski R, Alexandrowicz S, Bałaga K, Durakiewicz T and Pazdur A, 1999. Badania martwic wapiennych w obrębie źródliskowych torfowisk kopułowych we wschodniej Polsce (Research of the calcareous within domed spring mires in eastern Poland). In: Pazdur A, Bluszcz A, Stankowski W and Starkel L, Eds., Geochronologia Górnego Czwartorzędu $w$ Polsce $w$ świetle datowania radiowęglowego i luminescencyjnego. Wrocław, WIND-J. Wojewoda: 179-198 (in Polish).

Firbas F, 1949/1952. Spät- und nacheiszeitliche Waldgeschichte Mitteleuropas nördlich der Alpen. (Late and postglacial forest history of Central Europe north of the Alps). Band 1: Jena, Allgemeine Waldgeschichte: 480 pp. Band 2: Jena, Waldgeschichte der einzelnen Landschaften: 183-201 (in German).

Firbas F, 1954. Die Synchronisierung der mitteleuropäischen Pollendiagramme (The synchronization of the central European pollen diagrams). Danmarks Geologiske Undersøgelse II 80: 12-21 (in German).

Frenzel B, Eronen M, Vorren KD and Glaser B, 1993. Oscillations of the alpine and polar tree limits in the Holocene. Palaoklimaforschung 9, Akad.Wiss. und Literatur, Mainz: 234 pp.

Geyh MA, 1980. Holocene sea-level history:case study of the statistical evaluation of ${ }^{14} \mathrm{C}$ dates. Radiocarbon 22(3): 695-704.

Geyh MA and Jäkel D, 1974. Late Glacial and Holocene climatic history of the Sahara Desert from a statistical assay of ${ }^{14} \mathrm{C}$ dates. Palaeogeography, Palaeoclimatology, Palaeoecology 15(3): 205208, DOI 10.1016/0031-0182(74)90015-7.

Geyh MA and Streif H, 1970. Studies on coastal movements and sealevel changes by means of the statistical evaluations of ${ }^{14} \mathrm{C}$-data. Proceedings of Symposium 'Coastal Geodesy', Munich 1970: 599611.

Gil E, Gilot E, Szczepanek K, Kotarba A and Starkel L, 1974. An Early Holocene landslide in the Beskid Niski and its significance for palaeogeographical reconstructions. Studia Geomorphologica Carpatho-Balcanica 8: 69-83.

Godwin H, 1940. Pollen analysis and forest history of England and Wales. New Phytologist 39(4): 370-400, DOI 10.1111/j.14698137.1940.tb07149.x.

Godwin H, 1956. The History of the British Flora. A Factual Basis for Phytogeography. Cambridge, The University Press: 383 pp.

Godwin H, 1962. Half-life of Radiocarbon. Nature 195 (4845): 984, DOI 10.1038/195984a0.

Golthwait RP, 1966. Evidence from Alaskan glaciers of major climatic changes, in: World climate from 8000 to O B.C. Proceedings of International Symposium, Ryoal Meteorological Society, London: 15-33.

Goslar T, Arnold M and Pazdur M, 1998. Variations of atmospheric ${ }^{14} \mathrm{C}$ concentrations at the Pleistocene/Holocene trasition, reconstructed from the Lake Gościąż sediments. In: Ralska-Jasiewiczowa M, Goslar T, Madeyska T and Starkel L, eds, Lake Gościąż, central Poland. A monographic study. W Szafer Institute of Botany, Polish Academy of Sciences, Kraków: 162-171.

Goslar T, Bałaga K, Arnold M, Tisnerat N, Starnawska E, Kuźniarski M, Chróst L, Walanus A and Więckowski K, 1999. Climaterelated variations in the composition of the Lateglacial and Early Holocene sediments of Lake Perespilno (eastern Poland). Quaternary Science Reviews 18(7): 899-911, DOI 10.1016/S02773791(99)00004-9.

Goslar T, Hercman H and Pazdur A, 2000. Comparison of U-series and radiocarbon dates of speleothems. Radiocarbon 42(3): 403-414.
Goździk J and Pazdur MF, 1987. Frequency distribution of ${ }^{14} \mathrm{C}$ dates from Poland in the time interval $12-45 \mathrm{kyr} \mathrm{BP}$ and its paleogeographical implications. Zeszyty Naukowe Politechniki Ślaskiej, seria Matematyka-Fizyka, z. 56 Geochronometria 4: 27-42.

Gradziński M, Górny A, Pazdur A and Pazdur MF, 2003. Origin of black coloured laminae In speleothems from the Kraków-Wielun Upland, Poland. Boreas 32(3): 532-542, DOI 10.1111/j.15023885.2003.tb01233.x.

Gregory KJ, Benito G, Dikau R, Golosov V, Jones JA, Macklin MG, Parsons AJ, Passmore DG, Poesen J, Soja R, Starkel L and Walling DE, 2006. Past hydrological events related to understanding global change: an ICSU research project. Catena 66(1-2): 2-13, DOI 10.1016/j.catena.2005.11.011.

Grove J, 1988. The Little Ice Age. London - New York, Meuthen: 498 pp.

Hoek WZ, 2008. The Last Glacial-Interglacial Transition. Episodes 31(2): 226-229.

Hoek WZ, Yu ZC and Lowe JJ, 2008. INTegration of Ice-core, MArine, and TErrestrial records (INTIMATE): refining the record of the Last Glacial-Interglacial Transition. Quaternary Science Reviews 27(1-2): 1-5, DOI 10.1016/j.quascirev.2007.11.020.

Hormes A, Muller BU and Schluchter C, 2001. The Alps with little ice: evidence for eight Holocene phases of reduced glacier extent in the Central Swiss Alps. The Holocene 11(3): 255-265, DOI 10.1191/095968301675275728.

Jessen K, 1935. The composition of the forests in Northern Europe in epipalaeolithic time: Biologiske Meddelser 12(1): 64pp.

Kalicki T, 1991. The evolution of the Vistula river valley between Cracow and Niepołomice in the Late Vistulian and Holocene times. In: Starkel L, Ed), Evolution of the Vistula river valley during the last 15000 year. Part IV. Geographical Studies, Special Issue 6: 11-37.

Kalicki T and Krąpiec M, 1995. Problems of dating alluvium using buried subfossil tree trunks: lessons from the "black oaks" of the Vistula Valley, Central Poland. The Holocene 5(2): 243-250, DOI 10.1177/095968369500500213.

Kotarba A, 1995. Rapid mass wasting over last 500 years in the High Tatra Mountains. Quaestiones Geographicae, Special Issue 4: 177183

Kotarba A, 1996. Lacustrine sediments as an indicator of environmental changes in the High Tatra. Dokumentacja Geograficzna 4: 33-47 (in Polish with English summary).

Kotarba A, 2006. The Little Ice Age in the High Tatra Mounatins. Studia Quaternaria 23: 47-53.

Kotarba A and Baumgart-Kotarba M, 1997. Holocene debris flow activity in the light of lacustrine sediments studies in the High Tatra Mountains. Palaeoclimate Research 19: 147-158.

Kuc T, Różański K and Duliński M, 1998. Isotopic indicators of the Late-Glacial/Holocene transition recorded in the sediments of Lake Gościąż. In: Ralska- Jasiewiczowa M, Goslar T, Madeyska T and Starkel L, Eds., Lake Gościąż, Central Poland. A Monographic Study: 158-162.

Krąpiec M, 1992. Skale dendrochronologiczne późnego holocenu południowej i centralnej Polski (Late Holocene dendrochronological scales of southern and central Poland). Kwartalnik AGH - Geologia 18(3): 37-119.

Krąpiec M, 1996. Subfossil oak chronology (474 BC-AD 1529) from Southern Poland. In: Dean JS, Meko DM and Swetnam TW, Eds., Tree Rings, Environment and Humanity. Radiocarbon, Special Issue: $813-819$.

Krąpiec M, 1998. Oak dendrochronology of the Neoholocene in Poland. Folia Quaternaria 69: 5-134.

Krąpiec M, 2001. Holocene dendrochronological standards for subfossil oaks from the area of Southern Poland. Studia Quaternaria 18: 4763.

Kuzmin YV and Keates SG, 2005. Dates are not just data: Palaeolithic settlement patterns in Siberia derived from radiocarbon records American Antiquity 70(4): 773-789.

Lowe JJ, Rasmussen SO, Björck S, Hoek WZ, Steffensen JP, Walker MJC, Yu ZC and the INTIMATE group, 2008. Synchronisation of palaeoenvironmental events in the North Atlantic region during the 
Last Termination: a revised protocol recommended by the INTIMATE group. Quaternary Science Reviews 27(1-2): 6-17, DOI 10.1016/j.quascirev.2007.09.016.

Ložek V, 1964. Quartärmollusken der Tschechoslovakei (Quaternary mollusks of Czechoslovakia). Rozpravy Ustředniho Ustavu Geologického 31: 3-374 (in German).

Macklin MG, Benito G, Gregory KJ, Johnstone E, Lewin J, Michczyńska DJ, Soja R, Starkel L and Thorndycraft VR, 2006. Past hydrological events reflected in the Holocene fluvial record of Europe. Catena 66(1-2): 145-154, DOI 10.1016/j.catena.2005.07.015.

Magny M, 1993. Holocene fluctuation of lake levels in the French Jura and Sub-Alpine ranges, and their implications for past general circulation patterns. The Holocene 3(4): 306-313, DOI $10.1177 / 095968369300300402$.

Magny M, Begeot C, Guio, J and Peyron O, 2003. Contrasting patterns of hydrological change in Europe in response to Holocene climate cooling phases. Quaternary Science Reviews 22(15-17): 15891596, DOI 10.1016/S0277-3791(03)00131-8.

Mangerud J, Anderson ST, Berglund BE and Danner JJ, 1974. Quaternary stratigraphy of Norden, a proposal for terminology and classification. Boreas 3(3): 109-126 DOI 10.1111/j.15023885.1974.tb00669.x.

Margielewski W, 1998. Landslide phases in the Polish Outer Carpathians and their relation to climatic changes in the Late Glacial and the Holocene. Quaternary Studies in Poland 15: 37-53.

Margielewski W, 2001. Late Glacial and Holocene climatic changes registered in forms and deposits of the Klaklowo landslide (Beskid Średni Range, Outer Carpathians). Studia Geomorphologica Carpatho-Balcanica 35: 63-79.

Margielewski W, Ed., 2003. Late Glacial - Holocene palaeoenvironmental changes in the Western Carpathians: case studies of landslide forms and deposits. Folia Quaternaria 74: 96pp.

Margielewski W, 2006. Records of the Late Glacial-Holocene palaeoenvironmental changes in landslide forms and deposits of the Beskid Makowski and Beskid Wyspowy Mts. Area (Polish Outer Carpathians). Folia Quaternaria 76: 149pp.

Margielewski W, Krąpiec M, Valde-Nowak P and Zernitskaya V, 2010. A neolithic yew bow in the Polish Carpathians. Evidence of the impact of human activity on mountainous palaeoenvironment from the Kamiennik landslide peat bog. Catena 80(3): 141-153, DOI 10.1016/j.catena.2009.11.001.

Mayewski PA, Rohling EE, Stager JC, Karlen W, Maasch KA, Meeker LD, Meyerson EA, Gasse F, van Kreveld S, Holmgren K, LeeThorp J, Rosqvist G, Rack F, Staubwasser M, Schneider RR and Steig EJ, 2004. Holocene climatic variability. Quaternary Research 62(3): 243-255, DOI 10.1016/j.yqres.2004.07.001.

Michczyńska DJ and Hajdas I, 2010. Frequency Distribution of ${ }^{14} \mathrm{C}$ Dates for Chronostratigraphic Reconstructions: Study Case Alaska Region. Radiocarbon 52(2-3): 1041-1055.

Michczyńska DJ and Pazdur A, 2004. A shape analysis of cumulative probability density function of radiocarbon dates set in the study of climate change in Late Glacial and Holocene. Radiocarbon 46(2): 733-744.

Michczyńska DJ, Pazdur MF and Walanus A, 1990. Bayesian approach to probabilistic calibration of radiocarbon dates. PACT 29: 69-79.

Michczyńska DJ, Michczyński A and Pazdur A, 2007. Frequency distribution of radiocarbon dates as a tool for reconstructing environmental changes. Radiocarbon 49(2): 799-806.

Michczyńska DJ, Michczyński A, PazdurA and Starkel L, 2008. Kalendarzowe wartości granic chronostratygraficznych dla terenu Polski oszacowane na podstawie dużych zbiorów dat ${ }^{14} \mathrm{C}$ (calendar values of chronostratigraphic boundaries for Polish territory evaluated on the basis of large sets of ${ }^{14} \mathrm{C}$ dates). Prace Komisji Paleogeografii Czwartorzędu PAU, Kraków VI: 163-171 (in Polish with English summary)

Michczyński A and Michczyńska DJ, 2006. The efect of pdf peaks' height increase during calibration of radiocarbon date sets. Geochronometria 25: 1-4.

Nalepka D, 2005. Late Glacial and Holocene palaeoecological conditions and changes of vegetation cover under early farming activity in the south Kujawy region (central Poland). Acta Palaeobotanica, Supplement 6: 1-90.

Nalepka D and Walanus A, 2003. Data processing in pollen analysis. Acta Palaeobotanica 43(1): 125-134.

Neustadt MI, 1957. The history of forest and Holocene palaeogeography in the USSR. Moscow, USSR Academy of Sciences Press: 404 pp (in Russian).

Niedziałkowska E, Skubisz A and Starkel L, 1977. Lithology of the Eo - and Mesoholocene alluvia in Podgrodzie upon Wisłoka river. Studia Geomorphologica Carpatho-Balcanica 11: 89-100.

Niewiarowski W, 1987. Evolution of the lower Vistula valley in the Unisław Basin and the river gap to the North of Bydgoszcz Fordon. In: Starkel L, Ed., Evolution of the Vistula River Valley during the last 15,000 years. Geographical Studies, Special Issue 4(2): 234-252.

Niewiarowski W, Noryśkiewicz B, Piotrowski W and Sinkiewicz M, 1995. An outline of natural and anthropogenic changes of geographical environment in the Biskupin area during the last 7000 years. Quaternary Studies in Poland 13: 77-88.

Nowaczyk B and Okuniewska-Nowaczyk I, 1999. Wiek osadów biogenicznych i wybranych zdarzeń geomorfologicznych w Guzowie koło Lubska w świetle datowania radiowęglowego i palinologicznego (Age of biogenic sediments and selected geomorphological events In Guzów near Lubsko In the Ligot of radiocarbon and palynological dating). In: Pazdur A, Bluszcz A, Stankowski W and Starkel L, Eds., Geochronologia górnego czwartorzędu Polski: 265-275 (In Polish).

Nowaczyk B, Nalepka D and Okuniewska-Nowaczyk I, 2002. Rola człowieka prahistorycznego $\mathrm{w}$ kształtowaniu form i osadów na wybranych obszarach Niziny Wielkopolsko-Kujawskiej (The role of prehistoric man in the formation of forms and deposits on selected areas of the Wielkopolska-Kujawy Lowlands). Geographia. Studia et Dissertationes 25: 34-60 (in Polish with English summary).

Nilsson T, 1935. Die pollenanalytische Zonengliederung der spät- und post-glazialen Bildungen Schonens (The pollen zonation of the late-and post-glacial formations of Scania). Geologiska Föreningens i Stockholm Förhandlingar 57: 385-562 (in German).

Patzelt G, 1972. Die spätglazialen Stadien und postglazialen Schwankungen von Ostalpengletschern (The late glacial stages and postglacial fluctuations of Eastern Alpine glaciers). Berichte der Deutschen Botanischen Gesellschaft 85: 47-57 (in German).

Pazdur A, 1988. The relation between carbon isotope composition and apparent age of freshwater tufaceous sediments. Radiocarbon 30(1): 7-18

Pazdur A, 2000. Radiocarbon in freshwater carbonates as tool of Late Quaternary studies. Geologos 5: 135-154.

Pazdur A and Pazdur MF, 1986. Radiocarbon chronology of the Late Glacial period in Poland. Acta Interdisciplinaria Archaeologica IV: 61-71.

Pazdur A, Pazdur MF, Starkel J and Szulc J, 1988. Stable isotopes of the Holocene calcareous tufa in southern Poland as paleoclimatic indicators. Quaternary Research 30(2): 177-189, DOI 10.1016/0033-5894(88)90022-1

Pazdur A, Pazdur MF and Szulc J, 1988. Radiocarbon dating of Holocene calcareous tufa from south Poland. Radiocarbon 30: 133-146.

Pazdur A, Pazdur MF, Pawlyta J, Górny A and Olszewski M, 1995. Paleoclimatic implications of radiocarbon dating of speleothems from the Cracow-Wielun Upland, Southern Poland. In: Cook GT, Harkness DD, Miller BF and Scott EM, Eds., Proceedings of the 1994 Radiocarbon Conference. Radiocarbon 37(2): 103-110.

Pazdur A, Goslar T, Gradziński M and Hercman H, 1999a. Zapis zmian hydrologicznych i klimatycznych w obszarach krasowych Polski Południowej na podstawie badań izotopowych (Record of hydrological and climatic changes in the South Polish karst areas on the basis of isotopic studies). In: Pazdur A, Bluszcz A, Stankowski W and Starkel L, Eds., Geochronologia Górnego Czwartorzędu w Polsce $w$ świetle datowania radiowęglowego i luminescencyjnego. Wrocław, WIND-J. Wojewoda: 157-178 (in Polish).

Pazdur A, Goslar T, Pawlyta M, Hercman H and Gradziński M, 1999b. Variations of isotopic composition of carbon in the karst environ- 
ment from Southern Poland, present and past. Radiocarbon 41(1): 81-97.

Pazdur A, Dobrowolski R, Mohanti M, Piotrowska N and Srikanta D, 2002a. Radiocarbon time scale for deposition of the holocene calcareous tufaceous sediments from Poland and India (Orissa). Geochronometria 21: 85-96.

Pazdur A, Dobrowolski R, Durakiewicz T, Piotrowska N, Mohanti M and Sirkanta $\mathrm{D}, 2002 \mathrm{~b} . \delta^{13} \mathrm{C}$ and $\delta^{18} \mathrm{O}$ time record and palaeoclimatic implications of the Holocene calcareous tufa from SouthEastern Poland and Eastern India (Orissa). Geochronometria 21: 97-108.

Pearson GW and Stuiver M, 1986. High-precission bidecadal calibration of the radiocarbon time scale, $500-2500$ BC. Radiocarbon 28(2B): 839-862.

Peros MC, Munoz SE, Gajewski K and Viau AE, 2010. Prehistoric demography of north America inferred from radiocarbon data. Journal of Archaeological Science 37(3): 656-664, DOI 10.1016/j.jas.2009.10.029.

Ralska-Jasiewiczowa M, 1989. Environmental changes recorded in lakes and mires of Poland during the last 13,000 years. Acta Palaeobotanica 29: 1-120.

Ralska-Jasiewiczowa M and Latałowa M, 1996. Poland. In: Berglund BE, Birks HJB, Ralska-Jasiewiczowa M and Wright HE, Eds., Palaeoecological events during the last 15000 years. Chichester, New York, Brisbane, Toronto, Singapore, J. Wiley \& Sons: 403472.

Ralska-Jasiewiczowa M and Starkel L, 1988. Record of the hydrological changes during the Holocene in the lake, mire and fluvial deposits of Poland. Folia Quaternaria 57: 91-127.

Ralska-Jasiewiczowa M, Goslar T, Madeyska T and Starkel L, Eds., 1998. Lake Gościąż, Central Poland, a monographic study. Part 1. Kraków, W. Szafer Institute of Botany, Polish Academy of Sciences: $340 \mathrm{pp}$.

Ralska-Jasiewiczowa M, Goslar T, Różański K, Wacnik A, Czernik J and Chróst L, 2003. Very fast environmental changes at the Pleistocene/Holocene boundary, recorded in laminated sediments of Lake Gościąż, Poland. Palaeogeography, Palaeoclimatology, Palaeoecology 193(2): 225-247, DOI 10.1016/S0031-0182(03)00227$\mathrm{X}$.

Ralska-Jasiewiczowa M, Latałowa M, Wasylikowa K, Tobolski K, Madeyska T, Wright HE and Turner C, Eds., 2004. Late Glacial and Holocene history of vegetation in Poland based on isopollen maps. Kraków, W. Szafer Institute of Botany, Polish Academy of Sciences: 444 pp.

Rasmussen SO, Andersen KK, Svensson AM, Steffensen J-P, Vinther B, Clausen HB, Siggaard-Andersen ML, Johnsen SJ, Larsen LB, Dahl-Jensen D, Bigler M, Röthlisberge, R, Fischer H, GotoAzuma K, Hansson M and Ruth U, 2006. A new Greenland ice core chronology for the last glacial termination. Journal of Geophysical Research 111: D06102, DOI 10.1029/2005JD006079.

Reimer PJ, Baillie MGL, Bard E, Bayliss A, Beck JW, Blackwell PG, Bronk Ramsey C, Buck CE, Burr G, Edwards RL, Friedrich M, Grootes PM, Guilderson TP, Hajdas I, Heaton TJ, Hogg AG, Hughen KA, Kraiser KF, Kromer B, McCormac FG, Manning S, Reimer RW, Richards DA, Southon,JR, Talamo S, Turney CSM, van der Plicht $\mathrm{J}$ and Weyhenmeyer CE, 2009. IntCal09 and Marine09 radiocarbon age calibration curves, 0-50,000 years cal BP. Radiocarbon 51: 1111-1150.

Rick JW, 1987. Dates as data: an examination of the Peruvian preceramic radiocarbon record. American Antiquity 52(1): 55-73.

Różanski K, Klisch MA, Wachniew P, Gorczyca Z, Goslar T, Edwards TWDd, Shemesh A, 2010. Oxygen-isotope geothermometers in lacustrine sediments: New insights through combined $\delta^{18} \mathrm{O}$ analyses of aquatic cellulose, authigenic calcite and biogenic silica in Lake Gościąż, central Poland. Geochimica et Cosmochimica Acta 74: 2957-2969

Schirimer V, 1983. Die talentwicklung an Main und Regnitz seit dem Hochwürm (The development at Main and Regnitz since Upper Würm). Geologisches Jahrbuch A 71: 11-43 (in German).
Sernander R, 1908. On the evidence of postglacial changes of climate furnished by the peat-mosses of northern Europe. Geologiska Föreningens I Stockholms Förhandlingar 30: 456-478.

Starkel L, 1960. Evolution of the relief of Polisch flysch Carpathians during the Holocene. Prace Geograficzne IG PAN, Warszawa (in Polish).

Starkel L, 1966. The palaeogeography of Mid-and Eastern Europe during the last cold stage and West European comparison. Philosophical Transactions of the Royal Society London B 280: 351371.

Starkel L, 1977. Paleogeografia holocenu (Holocene palaeogeography). Warszawa, PWN: 362 pp (in Polish).

Starkel L, 1983. The reflection of hydrologic changes in the fluvial environment of the temperate zone during the last 15000 years. In: Gregory KJ, Ed., Background to Palaeohydrology. Chichester, J. Wiley and Sons: 213-237.

Starkel L, 1987. Anthropogenic sedimentological changes in Central Europe. Uppsala. Striae 26: 21-29.

Starkel L, 1991. Environmental changes at the Younger DryasPreboreal transition and during the early Holocene. The Holocene 1(3): 234-242, DOI 10.1177/095968369100100305.

Starkel L, 1995. Reconstruction of hydrological changes between 7000 and $3000 \mathrm{BP}$ in the upper and middle Vistula river basin, Poland. The Holocene 5(1): 34-42, DOI 10.1177/095968369500500105.

Starkel L, 1997. Mass movement during the Holocene: Carpathian example and the European perspective. In: Frenzel B, Ed., Rapid mass movement as a source of climatic evidence for the Holocene. Palaeoclimate Research 19: 385-400.

Starkel L, 1999. 8500-8000 yrs BP Humid Phase - Global or Regional? Science Reports of Tohoku University, $7^{\text {th }}$ Series, Geography 49(2) 105-133.

Starkel L, 2002. Changes in the frequency of extreme events as the indicator of climatic change in the Holocene (in fluvial systems). Quaternary International 91(1): 25-32, DOI 10.1016/S10406182(01)00099-4.

Starkel L, 2003. Short-term hydrological changes. In: Gregory KJ and Benito G, Eds., Paleohydrology, Understanding Global Change. Chichester, J. Wiley \& Sons: 337-356

Starkel L, 2005. Role of climatic and anthropogenic factors accelerating soil erosion and fluvial activity in central Europe. Studia Quaternaria 22 : 27-33

Starkel L, 2006a. Problems of Holocene climatostratigraphy on the territory of Poland. Studia Quaternaria 23: 17-21

Starkel L, 2006b. Clusterings of extreme rainfalls and evolution of fluvial systems in the Holocene. Studia Quaternaria 23: 23-28.

Starkel L, (Ed.), 1990. Evolution of Vistula river valley during last 15000 years. Part III, Warszawa, Geographical Studies, Special Issue 5.

Starkel L, (Ed.), 1991. Geografia Polski. Środowisko przyrodnicze (Polish geography. The natural environment). Warszawa, PWN: 669 pp (in Polish).Starkel L, Gregory KJ and Thornes JB, (Eds.), 1991. Temperate Paleohydrology: Fluvial Processes in the Temperate Zone During the Last 15,000 Years. John Wiley \& Son Ltd: $568 \mathrm{pp}$.

Starkel L, Kalicki T, Krąpiec M, Soja R, Gębica P and Czyżowska E, 1996a. Hydrological changes of valley floors in the Upper Vistula basin during late Vistulian and Holocene. Geographical Studies, Special Issue 9: 7-128.

Starkel L, Pazdur A, Pazdur MF, Wicik B and Więckowski K, 1996b. Lake-level and groundwater-level changes in the Lake Gościąż area, Poland: palaeoclimatic implications. The Holocene 6(2): 213224, DOI 10.1177/095968369600600207.

Starkel L, Goslar T, Ralska Jasiewiczowa M, Demske D, Różański K, Łącka B, Pelisiak A, Szeroczyńska K, Wicik B, Więckowski K, 1998. Discussion of the Holocene events recorded in the Lake Gościąż sediments. In: Ralska-Jasiewiczowa $\mathrm{M}$, Goslar $\mathrm{T}$, Madeyska T and Starkel L, Eds., 1998. Lake Gościąż, Central Poland, a monographic study. Part 1. Kraków, W. Szafer Institute of Botany, Polish Academy of Sciences: 239-251. 
Starkel L, Soja R and Michczyńska DJ, 2006. Past hydrological events reflected in Holocene history of Polish rivers. Catena 66(1-2): 2433, DOI 10.1016/j.catena.2005.07.008.

Stuiver M and Pearson GW, 1986. High-precission bidecadal calibration of the radiocarbon time scale, AD 1950-500 BC and 2500-6000 BC. Radiocarbon 28(2B): 805-838.

Stuiver M and Reimer PJ, 1986. A computer program for radiocarbon age calibration. Radiocarbon 28(2B): 1022-1030.

Szeroczyńska K, 1998. Holoceńska historia jezior Lednickiego Parku Krajobrazowego na podstawie kopalnych wioślarek (The Holocene history of lakes of Lednica Landscape Park based on subfossil Cladocera). Studia Geologica Polonica 112: 29-103 (in Polish).

Szeroczyńska K and Zawisza E, 2011. Records of the $8200 \mathrm{cal}$ BP cold event reflected in the composition of subfossil Cladocera in the sediments of three lakes in Poland. Quaternary International 233(2): 185-193, DOI 10.1016/j.quaint.2010.07.007.

De Vries HI, 1958. Variation in concentration of radiocarbon with time and location on earth. Koninkllijke Nederlandse Akademie van Wetenschappen Proceedings Serie B 61: 94-102.

Walanus A and Nalepka D, 2004. Calendar ages of the time horizons presented on the isopollen maps. In: Ralska-Jasiewiczowa M, Latałowa M, Wasylikowa K, Tobolski K, Madeyska T, Wright HE and Turner C, Eds., Late Glacial and Holocene history of vegetation in Poland based on isopollen maps. Kraków, W. Szafer Institute of Botany, Polish Academy of Sciences: 25-28.

Walanus A and Nalepka D, 2010. Calibration of Mangerud's Boundaries. Radiocarbon (52)4: 1639-1644.

Wiliams AN, 2012. The use of summed radiocarbon probability distributions in archaeology: a review of methods. Journal of Archaeological Science 39(3): 578-589.

Wojciechowski A, 1999. Late Glacial and Holocene lake-level fluctuations in the Kórnik-Zaniemyśl Lakes area, Great Poland Lowland. Quaternary Studies in Poland 16: 81-101.

Wójcik A, Mrozek T and Granoszewski W, 2006. Lithological conditioning of landslides and climatic changes with examples from the Beskidy Mts., Western Carpathians, Poland. Geografia Fisica e Dinamica Quaternaria 29: 197-200.

Zawisza E and Szeroczyńska K, 2007. The development history of Wigry Lake as shown by subfossil Cladocera. Geochronometria 27: 67-74, DOI 10.2478/v10003-007-0021-2.

Zoller H, 1977. Alter und Ausmass postglazialer Klimaschwankungen in den Schweizer Alpen (Age and extent of post-glacial climatic fluctuations in the Swiss Alps). In: Frenzel B, Ed., Dendrochronologie und postglaziale Klimaschwankungen in Europa (in German): 271-281. 